\title{
CHARACTERIZATION AND PYROLYSIS OF POST-CONSUMER LEATHER SHOE WASTE FOR THE RECOVERY OF VALUABLE CHEMICALS
}

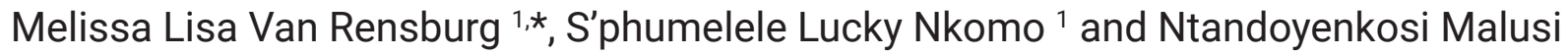 \\ Mkhize ${ }^{2}$ \\ ${ }^{1}$ University of KwaZulu-Natal, Discipline of Geography, 238 Mazisi Kunene Road, Glenwood, 4041 Durban, KwaZulu Natal, South Africa \\ 2 University of KwaZulu-Natal, Discipline of Chemical Engineering, 238 Mazisi Kunene Road, Glenwood, 4041 Durban, KwaZulu-Natal, South \\ Africa
}

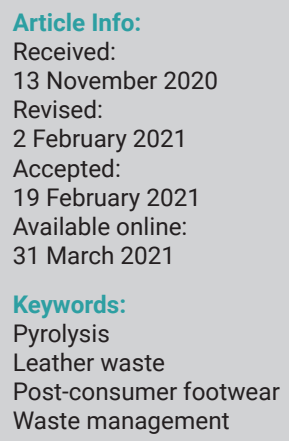

\begin{abstract}
Majority of post-consumer leather footwear currently ends up in landfill sites with adverse environmental impacts. Current waste recovery options have proven largely unsuccessful in minimizing this waste stream. This study investigates whether leather from post-consumer footwear can be pyrolyzed using gram-scale (fixed-bed) and microgram-scale (TGA) pyrolysis reactors. The investigation was conducted using final pyrolysis process temperatures between 450 and $650{ }^{\circ} \mathrm{C}$ and solid residence times of 5 to 15 minutes. The purpose of the experiments was to assess the waste recovery potential of leather pyrolysis products for valuable chemicals. The pyrolysis product fractions (solid, liquid, and gas) distribution were investigated, optimal pyrolysis conditions presented, and the product fractions characterized for their elemental and chemical composition using ultimate and GC-MS analysis. The distribution of the product fractions proved leather footwear pyrolysis was viable under the given conditions. The completion of leather footwear pyrolysis was evident at $650^{\circ} \mathrm{C}$ since the solid yield reached a constant value of approximately $25 \mathrm{wt} . \%$. The liquid fraction was maximized within the temperature range of $550-650^{\circ} \mathrm{C}$ (Max $\left.=54 \mathrm{wt} . \%\right)$, suggesting optimal pyrolysis conditions within this range. The higher heating values (HHVs) of the pyrolysis leather oil $(33.6 \mathrm{MJ} / \mathrm{kg})$ and char $(25.6 \mathrm{MJ} / \mathrm{kg})$ suggested their potential application for energy or fuel. The liquid fraction comprised predominantly of nitrogen derivatives and potential applications areas include use in the production of fertilizers, chemical feedstocks, or the pharmaceutical industry. This study proved that leather from post-consumer footwear can be pyrolyzed and provided valuable insight into its characterization and potential applications areas.
\end{abstract}

\section{INTRODUCTION}

Post-consumer shoe waste is a fundamental problem facing the footwear industry and waste management sectors. The footwear industry is rapidly growing, and it was estimated that in 2017 the production of shoes reached 23.5 billion pairs (Portuguese Shoes, 2018). The rapid production and consumption of footwear correspond to a substantial amount of post-consumer waste, the majority of which are currently disposed of in landfill sites (Kolomaznik et al., 2008, and Chowdhury, 2018). According to Mia et al. (2017), the most significant environmental challenge facing the footwear industry is the large amount of post-consumer waste generated in the End-of-Life (EoL) phase.

Leather waste constitutes a significant portion of waste emanating from the footwear industry because it is a prominent material used, with the average shoe constituting approximately $25 \%$ leather by weight (Staikos et al., 2006). Leather waste from post-consumer shoes is detrimental in its EoL phase because of the adverse environmental impacts associated with its disposal. Studies detailing the negative environmental impacts of leather shoe disposal highlight issues related to freshwater contamination, eutrophication, degradation of ecosystem quality, harmful emissions, and Global Warming Potential (GWP) (Albers et al., 2008, Joseph and Nithya, 2009, and Gottfridson and Zhang, 2015). Additionally, the footwear industry accounts for $1.4 \%$ of global climate impacts (Chrobot et al., 2018:18), and it is estimated that a single pair of leather shoes takes approximately 25-40 years to decompose in landfill sites (Fyvie, 2018). This study examines the poten- 
tial of pyrolysis as a waste recovery avenue to reduce the amount of post-consumer leather shoe waste disposed of in landfill sites.

According to Czajczyńska et al. (2017), pyrolysis is the thermochemical devolatilization of organic or inorganic materials at elevated temperatures in an inert atmosphere. The heating of materials through pyrolysis leads to the formation of solid, liquid, and gas fractions (Arabiourrutia et al., 2020). Pyrolysis is advantageous over other waste treatment processes such as incineration because the oxygen-free atmosphere in which pyrolysis takes place causes fewer $\mathrm{CO}_{2}$ emissions, thus lowering the greenhouse effect (Jo et al., 2017). Moreover, incineration and open combustion are inefficient waste recovery methods as the technology merely recovers energy while reducing the remainder of the materials to ash (Aylón et al., 2010). Murugan et al. (2008) state that pyrolysis technology can process the materials into three main fractions (solid, liquid, and gas) to recover valuable chemicals that would otherwise be lost during incineration or open combustion. These chemicals can be further processed into valuable products and hence improve waste recovery efficiency from materials. Food waste (Joe et al., 2017), plastic (Sorum et al., 2001, Olazar et al., 2009, and Sharuddin et al., 2016), and waste tyres (Islam et al., 2013, Perondi et al., 2016, and Lopez et al., 2017) are among some of the most widely studied materials using pyrolysis experiments. There are, however, limited studies that examine the potential of pyrolysis for recovering leather shoe waste.

Previous studies on leather pyrolysis focus mainly on waste from tanneries. A study on the production of useful materials from different types of leather tannery wastes was conducted by Yilmaz et al. (2007). The study investigated the experimental characteristics of leather waste pyrolysis at 450 and $600^{\circ} \mathrm{C}$. The pyrolysis experiments indicated that leather waste heated using a fixed bed reactor at 450 and $600^{\circ} \mathrm{C}$ yielded liquid, gas, and char products. Increasing the final temperature from 450 to $600^{\circ} \mathrm{C}$ caused the liquid yield to decrease from 32 to $28 \%$ and the gas yield to increase from 17 to $23 \%$. The authors emphasized the desirability of activated carbon, a refined version of the pyrolysis solid fraction (char), from pyrolyzed leather waste. Similarly, a study by Sethuraman et al. (2013) subjected hazardous chrome tanned leather waste (CTLW) from tanneries to pyrolysis to obtain valuable products. The main useful products generated through this process included carbonaceous residual ash containing chromium, condensate oil, and fuel gas (Sethuramen et al., 2013).

Marcilla et al. (2012) investigated the effect of flash $\left(450-550^{\circ} \mathrm{C}\right.$ ) and slow (up to $750^{\circ} \mathrm{C}$ ) pyrolysis on bovine leather from tanneries. Flash pyrolysis generally involves a faster heating rate and a shorter solid residence time compared to slow pyrolysis (Al Arni, 2018). Authors indicated that the maximum liquid yield (42-45\%) was achieved through flash pyrolysis between temperatures of 500$550^{\circ} \mathrm{C}$, while slow pyrolysis presented significantly lower levels of liquid yield (29\%). This finding is supported by literature indicating that flash pyrolysis generally optimizes the production of liquid yields while slow pyrolysis favors char as the main byproduct (Ronsse et al., 2012, and Al Arni, 2018). Kluska et al. (2019) focused on presenting the influence of temperature on the physicochemical properties of products obtained through the pyrolysis of leather tannery waste at lower temperature ranges. The leather waste was pyrolyzed at temperatures ranging from 300 to $500^{\circ} \mathrm{C}$. The authors concluded that a maximum liquid yield of $42 \%$ was obtained at $400^{\circ} \mathrm{C}$, followed by $40 \%$ at $500^{\circ} \mathrm{C}$. A summary of the main leather waste pyrolysis studies and their corresponding yields is presented in Table 1.

Previous studies contribute to knowledge generation about the recovery of leather tannery waste, but they do not address the issue of post-consumer leather waste specifically for footwear products. It can thus be inferred that a gap in the literature exists to investigate whether leather shoe waste can be pyrolyzed similarly to tannery waste

TABLE 1: Summary of previous leather pyrolysis studies.

\begin{tabular}{|c|c|c|c|c|c|c|c|c|}
\hline Reference & Pyrolysis type & $\begin{array}{c}\text { Temperature } \\
\left({ }^{\circ} \mathrm{C}\right)\end{array}$ & $\begin{array}{l}\text { Solid yield } \\
\text { (wt.\%) }\end{array}$ & $\begin{array}{l}\text { Liquid yield } \\
\text { (wt.\%) }\end{array}$ & $\begin{array}{c}\text { Gas yield } \\
\text { (wt.\%) }\end{array}$ & $\begin{array}{l}\text { Sample mass } \\
(\mathrm{g})\end{array}$ & Reactor & $\begin{array}{l}\text { Solid residence } \\
\text { time (min) }\end{array}$ \\
\hline $\begin{array}{l}\text { Sethuraman } \\
\text { et al. (2013) }\end{array}$ & Slow & 800 & 34.7 & 33.3 & 32.0 & 2000 & Fixed bed & n.a \\
\hline $\begin{array}{l}\text { Yilmaz et al. } \\
\text { (2007) }\end{array}$ & Slow & $\begin{array}{l}450 \\
600\end{array}$ & $\begin{array}{l}50.2 \\
47.4\end{array}$ & $\begin{array}{l}32.0 \\
28.9\end{array}$ & $\begin{array}{l}17.8 \\
23.6\end{array}$ & $50-60$ & Fixed bed & 120 \\
\hline $\begin{array}{l}\text { Marcilla et } \\
\text { al. (2012) }\end{array}$ & $\begin{array}{l}\text { Fast } \\
\text { Slow }\end{array}$ & $\begin{array}{l}450 \\
500 \\
550 \\
700\end{array}$ & $\begin{array}{l}38.5 \\
30.4 \\
31.0 \\
28.6\end{array}$ & $\begin{array}{l}41.0 \\
44.5 \\
42.3 \\
29.6\end{array}$ & $\begin{array}{l}20.5 \\
25.1 \\
26.6 \\
41.8\end{array}$ & $\begin{array}{l}2 \\
\\
4\end{array}$ & Fixed bed & n.a \\
\hline $\begin{array}{c}\text { Kluska et al. } \\
(2019)\end{array}$ & Slow & $\begin{array}{l}300 \\
350 \\
400 \\
450 \\
500\end{array}$ & $\begin{array}{l}33.0 \\
33.0 \\
33.0 \\
33.0 \\
29.0\end{array}$ & $\begin{array}{l}21.0 \\
35.0 \\
42.0 \\
35.0 \\
40.0\end{array}$ & $\begin{array}{l}46.0 \\
32.0 \\
25.0 \\
32.0 \\
31.0\end{array}$ & 100 & Fixed bed & 30 \\
\hline
\end{tabular}


to recover materials. This research is premised primarily as a concept proving and desirability study. The concept proving aspect is justified through the study's focus on investigating whether chrome tanned leather from post-consumer footwear has the potential to be pyrolyzed through experimental runs. The optimization of pyrolysis yields was also investigated through experimental runs, and this constituted the desirability aspect of the study. The novelty of the study reveals itself in the fact that leather from post-consumer footwear has yet to be pyrolyzed and hence motivates the need for this study as footwear presents challenges in the EoL phase.

The present study therefore examined waste recovery by thermochemical treatment by conducting pyrolysis experiments using samples of solid leather waste from post-consumer shoes. The main aim of this study was to assess the waste recovery potential of leather pyrolysis products for valuable chemicals. The aim was achieved through the following investigations (i) leather footwear pyrolysis experiments using fixed bed and TGA pyrolysis reactors; (ii) an analysis of the pyrolysis product distribution and optimal operating conditions; (iii) characterization of the elemental and chemical composition of the pyrolysis product yields using ultimate and GC-MS analysis, including an analysis of the higher heating value (HHV).

\section{MATERIALS AND METHODS}

\subsection{Leather feedstock}

Samples of leather shoes were obtained from various local shoe producers for pyrolysis. The samples consisted of reject shoes which are considered waste as they can no longer be used or sold. The shoe samples consisted of chrome tanned leather which was separated from the shoe soles to obtain leather in isolation from the other materials. The leather was cut into smaller pieces with particle sizes of approximately $0.5 \mathrm{~cm}$. The shredded leather from various shoes was mixed before use in the experimental pyrol- ysis runs to ensure feedstock homogeneity. The weight of each sample was $40 \mathrm{~g}$.

Preliminary experimental preparations included characterizing the sample material. To characterize and understand the constituents of the sample material, a proximate and ultimate analysis was conducted. The proximate analysis was performed to determine the major constituents of the feed material used in pyrolysis, while the ultimate analysis provided an elemental composition of the material (Basu, 2018). The results of the proximate and ultimate analyses of leather shoe waste are depicted in Table 2. The results are shown in comparison to previous studies which have been conducted on leather waste. These characteristics are essential to understand as they provide a broad understanding of the combustion characteristics of solid leather shoe waste.

\subsection{Experimental setup}

\subsubsection{Fixed bed reactor}

The pyrolysis unit chosen for this study was a fixed bed reactor. The fixed bed pyrolysis system comprised of a fixed bed of feedstock which was pyrolyzed as a batch reaction (Guda et al., 2015). The main features of the fixed bed reactor used in this study included a sample capacity of approximately $\pm 45 \mathrm{~g}$ (depending on the density and type of material) and a reactor temperature range between $0-1200^{\circ} \mathrm{C}$. The dimensions of the fixed bed reactor can be found in Figure 1. The fixed bed reactor provided technology that was reliable and simple for the research purposes in this study (Aziz et al., 2018). A fixed bed reactor feedstock system was thus suitable for this research study as it was conducted on a small-scale for research purposes and allowed for a proof of the concept.

\subsubsection{Pyrolysis system}

The pyrolysis system used in this study is illustrated in Figure 1. This system involved the input of the leather waste feedstock into the sample holder placed inside of

TABLE 2: Ultimate and proximate analysis of leather waste in previous studies.

\begin{tabular}{|c|c|c|c|c|c|c|c|}
\hline Reference & $\begin{array}{l}\text { Sethuraman et al. } \\
\qquad(2013)\end{array}$ & $\begin{array}{l}\text { Yilmaz et al. } \\
(2007)\end{array}$ & $\begin{array}{l}\text { Marcilla et al. } \\
\quad(2012)\end{array}$ & $\begin{array}{l}\text { Kluska et al. } \\
\text { (2019) }\end{array}$ & $\begin{array}{l}\text { Rodrigues et al. } \\
\text { (2010) }\end{array}$ & $\begin{array}{l}\text { Godinho et al. } \\
\text { (2011) }\end{array}$ & $\begin{array}{l}\text { Present } \\
\text { study }\end{array}$ \\
\hline \multicolumn{8}{|l|}{$\begin{array}{l}\text { Proximate analysis } \\
\text { (wt. \%) }\end{array}$} \\
\hline Moisture content & 5.50 & 7.10 & 11.20 & 35.30 & 12.40 & 14.10 & 12.56 \\
\hline Volatile matter & 60.30 & 67.00 & 76.70 & 67.90 & 67.70 & 66.40 & 61.23 \\
\hline Fixed carbon & 26.62 & n.d & 6.12 & 21.20 & 14.80 & 14.52 & 18.77 \\
\hline Ash & 7.58 & 9.60 & 6.03 & 10.90 & 5.10 & 4.95 & 7.44 \\
\hline \multicolumn{8}{|l|}{$\begin{array}{l}\text { Ultimate analysis } \\
(\text { wt. \% })^{a}\end{array}$} \\
\hline Carbon & 55.31 & 44.30 & 41.50 & 41.71 & 50.61 & 42.36 & 38.93 \\
\hline Hydrogen & 7.86 & 3.10 & 6.85 & 7.12 & 8.79 & 7.32 & 5.62 \\
\hline Oxygen ${ }^{b}$ & 8.54 & 36.60 & 37.90 & 28.46 & 25.46 & 19.00 & 32.36 \\
\hline Nitrogen & 12.56 & 14.20 & 12.90 & 11.01 & 12.80 & 10.67 & 8.88 \\
\hline Sulfur & 4.68 & 1.80 & 0.83 & 3.43 & 1.89 & 1.57 & 1.65 \\
\hline
\end{tabular}

a Dry basis

${ }^{b}$ By difference 


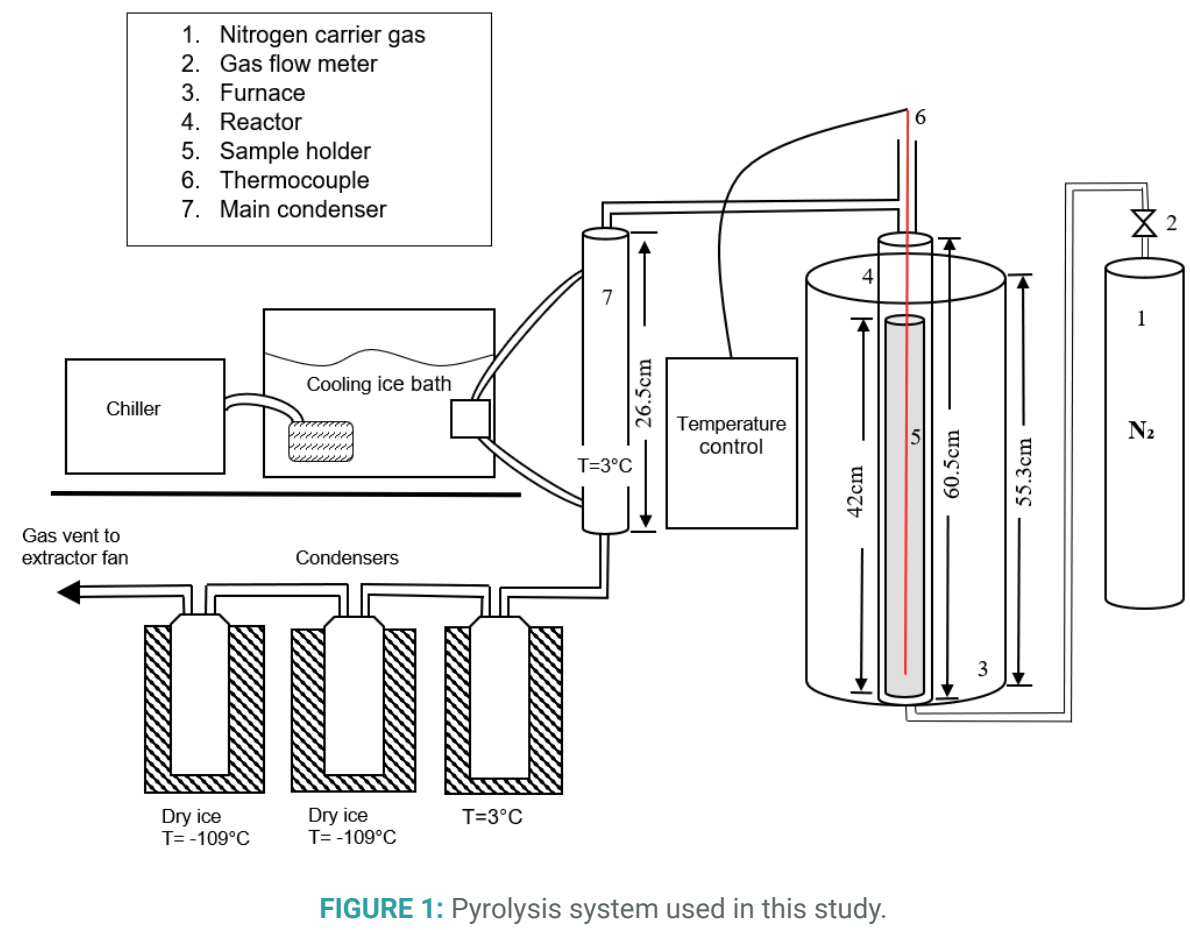

the fixed bed reactor. The feedstock was exposed to high temperatures within the fixed bed reactor in the absence of oxygen. The flow of the nitrogen $\left(\mathrm{N}_{2}\right)$ carrier gas created an inert atmosphere within the system. As the feedstock was heated, it experienced physical and chemical separation into different molecules. The thermal devolatilization led to the formation of products in the form of solids (char) and volatiles (condensable and non-condensable or permanent gases) (Hirvonen, 2017). The liquid only formed from the condensable volatiles when it cooled in the condenser to allow separation into pyrolysis oil and permanent gas. The cooling system used as a part of the pyrolysis unit was a chiller and an ice bath which was connected to the condenser to enable a cold temperature ranging between $1-3^{\circ} \mathrm{C}$. Three collectors ensued after the condenser, and these were placed in dry ice to ensure sufficient time to allow further condensation of the high volatile condensables to liquid products from the leather feedstock. The inclusion of the last two condensers was motivated by the additional liquid fractions observed in these condensers. These condensers allowed for further condensation and therefore accounted for all liquid fractions. The non-condensable gases flowed through a vent into an extractor fan.

\subsection{Experimental design}

The processing factors considered in the experimental design of this study were temperature, solid residence time, and $\mathrm{N}_{2}$ flow rate. The temperature range, solid residence time, and center points were chosen based on the typical ranges cited in the literature and the operability range of the existing pyrolysis setup.

Operating temperature is the most critical parameter in Thermochemical Conversions (TCCs) because the temperature of the reactor is directly correlated to the product yields obtained (He et al., 2000). For this study, the operating temperatures chosen were 450,550 , and $650^{\circ} \mathrm{C}$, including lower and higher axial points of 409 and $691^{\circ} \mathrm{C}$, respectively (Table 3 ). Previous studies were considered when selecting the temperature range used in the present study (Yilmaz et al., 2007, Marcilla et al., 2012, and Kluska et al., 2019). The center point temperature chosen for pyrolysis $\left(550^{\circ} \mathrm{C}\right)$ was motivated by the fact that pyrolysis appears to be complete by this temperature as the majority of the sample devolatilization has taken place in this range. Choosing the temperature range of 450 and $650^{\circ} \mathrm{C}$ with a center point of $550^{\circ} \mathrm{C}$ enables the researcher to draw parallels with previous studies to verify whether pyrolysis of leather shoe waste is achievable in a comparable manner to leather tannery waste (Yilmaz et al., 2007, Marcilla et al., 2012, and Kluska et al., 2019). The use of different temperature ranges in the pyrolysis reactor enabled the researcher to determine the differences in product yields and the optimal conditions for leather footwear pyrolysis.

Solid residence time refers to the amount of time that the feedstock remains inside the reactor (Gao et al., 2017). The solid residence time used in pyrolysis studies is an important parameter that can influence product yields (Dhyani and Bhaskar, 2018). For this study, the solid residence time reflects the amount of time the sample was held inside the reactor once the processing temperature was met. The hold times used in this study had a center point of 10 minutes and lower and upper levels of 5 and 15 minutes, respectively (Table 3 ). The lower and higher axial points are 3 and 17 minutes, respectively. The continuous flow of N2 gas flow created an oxygen-free atmosphere within the reactor (Aziz et al., 2018). An inert atmosphere is imperative as it creates conditions which are chemically inactive to ensure pyrolysis takes place without the risk of contamination from oxidizing gases such as oxygen (Jo et 
TABLE 3: Central composite design (CCD) factors.

\begin{tabular}{|c|c|c|c|c|c|c|c|}
\hline Factor & Unit & Factor type & $\begin{array}{c}\text { Lower level } \\
(-1)\end{array}$ & $\begin{array}{l}\text { Center point } \\
(0)\end{array}$ & $\begin{array}{c}\text { Upper level } \\
(+1)\end{array}$ & $\begin{array}{c}\text { Lower axial } \\
(-1.414)\end{array}$ & $\begin{array}{c}\text { Higher axial } \\
(+1.414)\end{array}$ \\
\hline Temperature & ${ }^{\circ} \mathrm{C}$ & Variable & 450 & 550 & 650 & 409 & 691 \\
\hline Solid residence time & $\min$ & Variable & 5 & 10 & 15 & 3 & 17 \\
\hline Nitrogen flow rate & $\mathrm{L} / \mathrm{min}$ & Constant & \pm 6.5 & \pm 6.5 & \pm 6.5 & \pm 6.5 & \pm 6.5 \\
\hline Particle size & $\mathrm{cm}$ & Constant & 0.5 & 0.5 & 0.5 & 0.5 & 0.5 \\
\hline Sample amount & $\mathrm{g}$ & Constant & 40 & 40 & 40 & 40 & 40 \\
\hline Solid yield & wt. \% & Response & & & & & \\
\hline Liquid yield & wt.\% & Response & & & & & \\
\hline Gas yield & wt.\% & Response & & & & & \\
\hline
\end{tabular}

al., 2017). The nitrogen flow rate ( $99.5 \%$ purity, Afrox, South Africa) remained constant at $6.5 \mathrm{~L} / \mathrm{min}$ for the pyrolysis experiments in this study. It was essential to ensure the nitrogen flow rate remained constant to provide a controlled inert atmosphere and to prevent counter airflow that may have compromised the experimental runs.

This study used a two-level full factorial design with a replication of experiments to verify the results. A central composite design (CCD) was employed with three center points, and an overview of the design and response factors are provided in Table 3. This experimental design enabled the researcher to investigate the optimization of operating conditions for pyrolysis yields. A statistical analysis of the variance was also employed using Minitab ${ }^{\circledR} 19$ Statistical Software. A response surface model was fitted to determine the effects of temperature and solid residence time on each of the pyrolysis yields. Moreover, this also aided the researcher in identifying conditions that optimized the pyrolysis yields within the study.

\subsection{Mass balance}

The mass balance was a central component used to calculate the yields for each experimental pyrolysis run. The reactor and condensers were weighed before and after each pyrolysis experiment to calculate the percentage of solid, liquid, and gas yields. The difference in weight within the reactor was attributed to the remaining char whilst the difference in the condenser weight was attributed to the liquid yield. The gas yield was calculated using the difference in weight, and hence the remaining fraction was allocated to the gas yield.

\subsection{Analytical techniques}

\subsubsection{Thermogravimetric analysis}

Thermogravimetric analysis (TGA) was one of the analytical methods employed in this study. Through TGA, it was possible to assess the weight loss function of temperature under the nitrogen atmosphere (Sethuraman et al., 2013). According to Januszewicz et al. (2016), TGA enables users to determine the characteristics of the temperature dependence of weight loss at a constant heating rate. TGA assumes that several products can form from a single substrate (Januszewicz et al., 2016). It can, therefore, be inferred that the number and types of products formed from the leather waste were proportional to changes in mass decomposition.

In this study, TGA experiments were performed on chrome-tanned leather waste using a sample mass of $10 \pm 0.5 \mathrm{mg}$ and particle size ranges of 0.5 to $0.8 \mathrm{~mm}$. The samples were inserted into $70 \mu \mathrm{L}$ alumina sample holders and experiments were performed using the DTG-60AH detector (Shimadzu, Kyoto, Japan). The temperature range was between 25 and $800^{\circ} \mathrm{C}$, and the heating rate was $25^{\circ} \mathrm{C} / \mathrm{min}$. An inert atmosphere was created using nitrogen (99.5\% purity, Afrox, South Africa) with a flow rate of $80 \mathrm{ml} /$ min. TGA experiments were carried out three times to ensure reproducibility of the observed results.

\subsubsection{Elemental analysis}

The second analytical technique used in this study was an elemental analysis, which is also known as an ultimate analysis. This is the process through which the sample of leather material was analyzed for its elemental composition (Basu, 2018). The elemental composition in terms of Carbon, Hydrogen, Nitrogen, and Sulfur (CHNS) was determined for the raw leather shoe waste, the residual char, and the liquid oil fractions. This analysis was used to determine the ratio of elements from within the leather samples and the composition of the solid and liquid pyrolytic yields. The instrument used for this analysis was the Thermo Fisher Scientific Flash 2000 CHNS-O Organic Elemental Analyzer. The results of the ultimate analysis $(\mathrm{C}, \mathrm{H}, \mathrm{N}$ and $\mathrm{O}$ content) were also used to estimate the higher heating values (HHVs) of the pyrolysis product fractions using the correlation equation (1) (Mkhize et al., 2015, and Demirbas, 2016). The HHV is significant as it provides an indication of the amount of heat released and hence the energy density of the solid and liquid fractions.

$H H V=33.5[\mathrm{C}]+142.3[\mathrm{H}]-15.4[\mathrm{O}]-14.5[\mathrm{~N}] \times 10^{-2}$

\subsubsection{Gas chromatography-mass spectrometry}

Gas chromatography-mass spectrometry (GC-MS) (Shimadzu GC-MS QP2010SE series model) was used to detect compounds from the liquid yield. The compounds were detected using the gas chromatographic retention times and identified in the mass spectrometer. The sample was swept through a capillary column (Zebron ZB-5MSplus $30 \mathrm{~m} \times 0,25 \mathrm{~mm}, 0,25 \mathrm{um}$ id). using helium (99.9\% purity, Air products, South Africa) as the carrier gas and components were separated based on the volatility and affinity of the 
mixture. The method used for the analysis was as follows: the initial temperature was set at $40^{\circ} \mathrm{C}$; the final temperature was set at $270^{\circ} \mathrm{C}$; the heating rate was $10^{\circ} \mathrm{C}$ per minute, and the total time for the run was 48 minutes. A qualitative analysis of the chromatogram was conducted using the NIST mass spectral library (version 4.0) to identify the compounds present in the liquid yield. Since the qualitative analysis was used the researcher emphasized determining what constituted the liquid yields rather than determining exactly how much of each compound was present. The qualitative nature of the study is elaborated on in the following section.

\subsection{Concept proving and desirability study}

This research was premised primarily as a concept proving and desirability study. The focus was placed on establishing whether chrome tanned leather from post-consumer footwear has the potential to be pyrolyzed. Pyrolysis experimental runs were used to determine optimal conditions for pyrolysis product yields, and this constituted the desirability aspect of the study. The quantities of the pyrolysis yields were considered concerning the processing temperature and solid residence time. In addition, the emphasis was placed on the replication of pyrolysis experimental runs to ensure the validity of the research findings. The GC-MS had a qualitative focus in its methodology for the analysis of the liquid yields. The constituents of the liquid yields were analyzed in this study with a greater focus on the composition of the yield rather than the quantities.

\section{RESULTS AND DISCUSSION}

\subsection{Thermogravimetric analysis}

The thermogravimetric analysis (TGA) of chrometanned leather samples for a heating rate of $25^{\circ} \mathrm{C} / \mathrm{min}$ revealed that the first mass loss of the sample is apparent between 0 and $150^{\circ} \mathrm{C}$ (Figure 2). The mass loss observed in this temperature range is attributed to the release of inherent moisture contained within the sample. Yilmaz et al. (2007) describe this component of the liquid yield as the aqueous phase. An explanation for this peak is that the pyrolysis temperature reached close to $100^{\circ} \mathrm{C}$, which is the temperature at which water evaporates (Kluska et al., 2019). According to Pham et al. (2018) water absorbs heat and uses it to evaporate and can also play a role in delaying devolatilization. The majority of the mass loss is observed between 250 and $550^{\circ} \mathrm{C}$, with the most significant mass release peak occurring at $350^{\circ} \mathrm{C}$ (Figure 2). A $50 \%$ reduction in mass was experienced between 250 and $550^{\circ} \mathrm{C}$ resulting in the large weight loss peak in the DTG curve. This mass release is caused by the thermal devolitilisation of volatile organic compounds present in the leather sample. The maximum temperature peak demonstrates the significant impact that heat transport has on forming the mass loss curves. The TGA curve begins to flatten after $550^{\circ} \mathrm{C}$ indicating the near completion of pyrolysis. Additionally, it is observed that after pyrolysis is complete, the remaining mass accounts for approximately $25 \mathrm{wt}$.\% of the sample (Figure 2).

\subsection{Pyrolysis yields from leather shoe waste}

This section outlines the product yields as a result of pyrolyzing leather shoe waste. Available data from the literature indicates that the mass balance of different types of pyrolysis products is dependent on the final temperature in the pyrolysis process (Yilmaz et al., 2007, and Xiao and Yang, 2013). The effect of temperature and solid residence time on the pyrolysis yields (solid, liquid, and gas) were investigated through CCD experiments according to the parameters outlined in Table 3. The results obtained from the CCD experiments are summarized in Table 4. The averages of the solid, liquid, and gas yields are presented in conjunction with the standard deviation (SD) in Table 4.

\subsubsection{Solid yield}

The solid yield consisted of char, a carbonaceous material generated through the thermal devolatilization of leather in the pyrolysis reactor. The solid yields ranged between

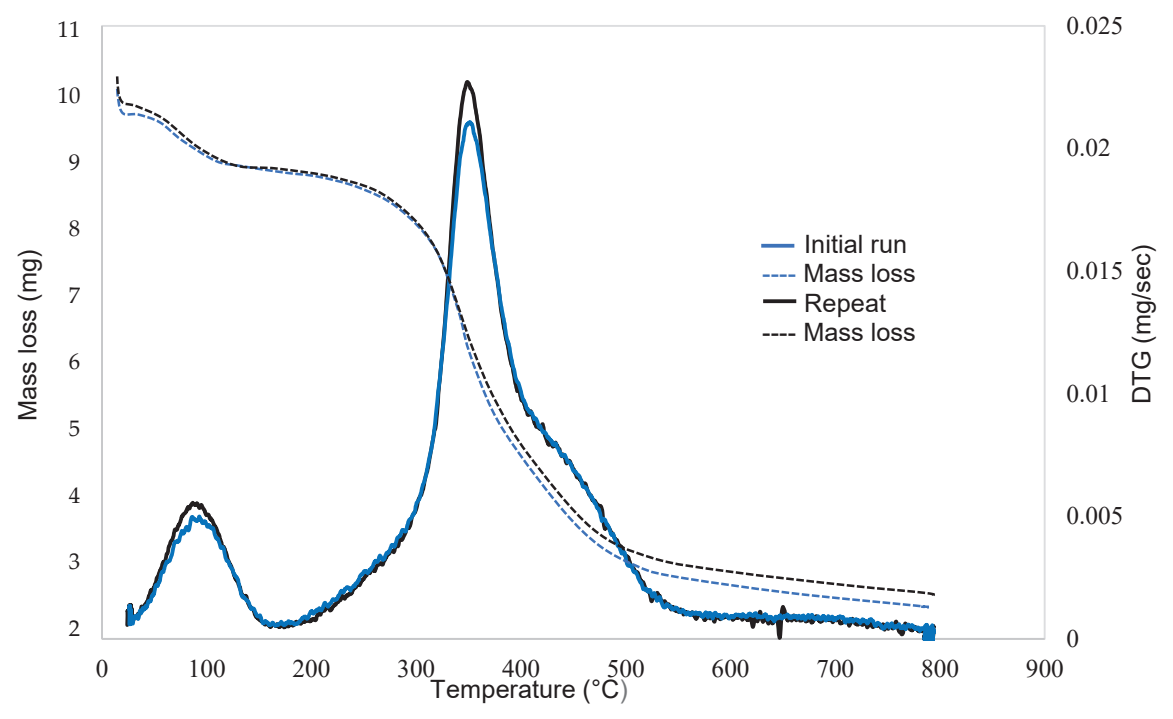

FIGURE 2: TGA and mass loss curve for leather waste in a nitrogen atmosphere with a heating rate of $25^{\circ} \mathrm{C} / \mathrm{min}$. 
TABLE 4: Central Composite Design (CCD) of experiments

\begin{tabular}{|c|c|c|c|c|c|}
\hline \multirow[t]{2}{*}{ Run no. } & \multicolumn{2}{|c|}{ Pyrolysis parameters } & \multicolumn{3}{|c|}{ Leather pyrolysis products } \\
\hline & Temperature $\left({ }^{\circ} \mathrm{C}\right)$ & Time (min) & Solid yield (wt.\%) & Liquid yield (wt.\%) & Gas yield ${ }^{a}$ (wt.\%) \\
\hline & & & Average $\pm S D$ & Average $\pm \mathrm{SD}$ & Average $\pm S D$ \\
\hline 1. & 409 & 10 & $42.63 \pm 0.88$ & $38.43 \pm 3.01$ & $19.00 \pm 2.12$ \\
\hline 2. & 450 & 5 & $38.38 \pm 2.30$ & $45.50 \pm 1.06$ & $16.13 \pm 3.36$ \\
\hline 3. & 450 & 15 & $33.50 \pm 0.71$ & $46.88 \pm 2.30$ & $21.30 \pm 5.13$ \\
\hline 4. & 550 & 3 & $29.63 \pm 1.59$ & $49.63 \pm 3.36$ & $20.75 \pm 4.95$ \\
\hline 5. & 550 & 10 & $27.75 \pm 2.47$ & $52.63 \pm 1.94$ & $19.63 \pm 4.42$ \\
\hline 6. & 550 & 17 & $27.75 \pm 2.30$ & $40.38 \pm 1.94$ & $32.25 \pm 4.24$ \\
\hline 7. & 650 & 5 & $24.75 \pm 1.06$ & $51.75 \pm 2.47$ & $23.50 \pm 3.54$ \\
\hline 8. & 650 & 15 & $24.63 \pm 0.88$ & $46.25 \pm 2.12$ & $29.13 \pm 3.01$ \\
\hline 9. & 691 & 10 & $24.50 \pm 0.00$ & $46.63 \pm 2.30$ & $28.88 \pm 2.30$ \\
\hline
\end{tabular}

${ }^{a}$ By difference

42.63 to 35.94 wt.\% at temperatures of 409 and $450^{\circ} \mathrm{C}$, respectively (Table 4 ). This change in mass indicates that at lower temperatures, pyrolysis was incomplete. Molecular components were unable to devolatilise at lower temperatures fully and only the weak chemical bonds were broken (He et al., 2018). These yields are congruent with previous studies that revealed solid fractions from leather tannery waste between a similar range of 33 and $38.5 \mathrm{wt} . \%$ at $450^{\circ} \mathrm{C}$ (Marcilla et al., 2015, Kluska et al., 2018, and Fang et al., 2018). Moreover, at $550^{\circ} \mathrm{C}$, the present study indicated a mass of $28.25 \mathrm{wt}$ \% that is consistent with the yields obtained by Marcilla et al. (2012). The similar solid yields between studies reveal that leather waste from shoes can be pyrolyzed to yield similar results to leather tannery waste.

The response surface model in Figure 3 provides a visual representation of the interactions between temperature and hold time on the solid yield. It is observed that there is a negative correlation between temperature and solid yield because an increase in temperature corresponds to a decrease in the solid yield. As the temperature increases past $600^{\circ} \mathrm{C}$, the response surface begins to flatten with lower yields indicating the near completion of pyrolysis. The relationship between solid residence time and solid yield appears to be less significant compared to temperature. This is because only minor differences in the solid fraction distribution were observed as a function of the hold time.

The solid yield reached a constant value of approximately $25 \mathrm{wt} . \%$ at $650^{\circ} \mathrm{C}$, indicating the completion of leather pyrolysis under CCD conditions. The completion of pyrolysis can be verified since the solid yield remaining corresponds to the fixed carbon and ash proportions of the leather sample in Table 2. This is further verified through an examination of the remaining mass in TGA experiments which accounts for approximately 25 wt.\% of the sample (Figure 2). The char yields obtained through pyrolysis operating at two different scales are illustrated in Table 5. The fixed bed pyrolyzer operated using a gram-scale whilst the TGA operated using a microgram-scale. The yields are comparable since the solid fractions are similar for both setups. The slight variations in the wt. \% may be attributed

\section{Solid yield}

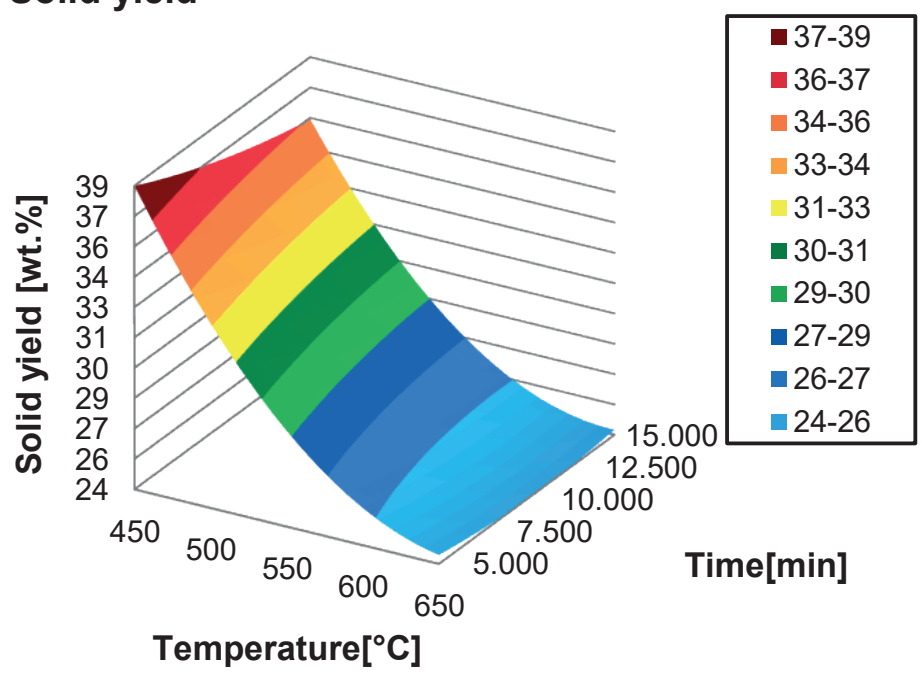

FIGURE 3: . Response surface model illustrating the effect of temperature and hold time on solid yield. 
TABLE 5: Solid yields for CCD pyrolysis and TGA experiments.

\begin{tabular}{c|c|c}
\hline Temperature $\left({ }^{\circ} \mathrm{C}\right)$ & Fixed bed pyrolyzer (wt. \%) & TGA (wt. \%) \\
\hline 409 & 42.63 & 46.85 \\
\hline 450 & 36.94 & 39.17 \\
\hline 550 & 28.25 & 30.45 \\
\hline 650 & 24.69 & 28.45 \\
\hline 690 & 24.5 & 27.56 \\
\hline
\end{tabular}

TABLE 6: Elemental composition of char obtained from leather shoe waste.

\begin{tabular}{c|cc} 
Components & Char (wt. \%) & TGA (wt. \%) \\
\hline Nitrogen & 8.69 & 46.85 \\
\hline Carbon & 62.67 & 39.17 \\
\hline Hydrogen & 2.36 & 30.45 \\
\hline Sulfur & 0.74 & 28.45 \\
\hline Oxygen $^{\mathrm{b}}$ & 12.98 & 27.56 \\
\hline
\end{tabular}

${ }^{a}$ Dry basis ${ }^{b}$ By difference.

to differences in the heating rates across the two setups. TGA had a controlled heating rate whilst the fixed bed pyrolyzer had a heating rate that was more variable and hence less constant in comparison. The comparability of the findings at different scales, as well as the consistency of the char yields with the fixed carbon and ash content, verifies the completion of pyrolysis under CCD conditions and further suggests the suitability of leather shoes for pyrolysis technology.

The elemental composition of char generated from leather shoe waste pyrolysis is shown in Table 6, with carbon taking the largest share of the composition. The higher heating value of the solid fraction was determined to be $25.55 \mathrm{MJ} / \mathrm{kg}$. The char generated through pyrolysis could be used in the metallurgical sector. According to Filho et al. (2016), carbonized leather residues have the potential to partially replace coal in the metallurgical process, especially if they have a high heating value of $20.8 \mathrm{MJ} / \mathrm{kg}$. Since the $\mathrm{HHV}$ was $25.55 \mathrm{MJ} / \mathrm{kg}$ in this study this reinforces its potential use in this sector. Moreover, Bañón et al. (2016) pointed out that char may be used as cheap fuel, either pure or blended with other fuels. Yilmaz et al. (2007) also reported that char products from pyrolyzed leather could be used in the production of activated carbon and as an adsorbent of dyes from aqueous solutions.

\subsubsection{Liquid yield and analysis}

The liquid yield ranged between 36.25 and 54 wt.\% at temperatures of 409 and $550^{\circ} \mathrm{C}$, respectively. An increase in the process temperature corresponded to a rise in the liquid yield up to $550^{\circ} \mathrm{C}$. It has been well documented that tar formation rate should increase with an increase in the pyrolysis temperature (Xiao and Yang, 2013, Bañón et al., 2016, and Baniasadi et al., 2016). The liquid fraction was maximized within the temperature range of $550-650^{\circ} \mathrm{C}$. This finding is affirmed in Figure 4 since the liquid yield peaks between 550 and $650^{\circ} \mathrm{C}$. The convex profile of the response surface reveals a well-defined optimum condition for the liquid yield. The highest liquid yield was achieved at $550^{\circ} \mathrm{C}$ with a hold time of 10 minutes (54 wt.\%), and a close second was observed at $650^{\circ} \mathrm{C}$ with a hold time of 5 minutes (53.5 wt.\%) (Table 4). The current findings are supported by Marcilla et al. (2012) and Kluska et al. (2019), who observed the maximum liquid yields within a similar temperature range of $500-550^{\circ} \mathrm{C}$. The general findings from the CCD experiments and the convex shape of the response surface suggest that leather waste from shoes can be pyrolyzed between an optimal temperature range of $550-650^{\circ} \mathrm{C}$.

Lower liquid yields were evident at lower temperatures corresponding with high solid yields. For instance, a liquid yield of 36.25 (wt.\%) was reached at $409^{\circ} \mathrm{C}$ whilst solid yields remained high, accounting for 42.63 (wt.\%) of the yield at $409^{\circ} \mathrm{C}$. Since polymeric components could not fully

\section{Liquid yield}

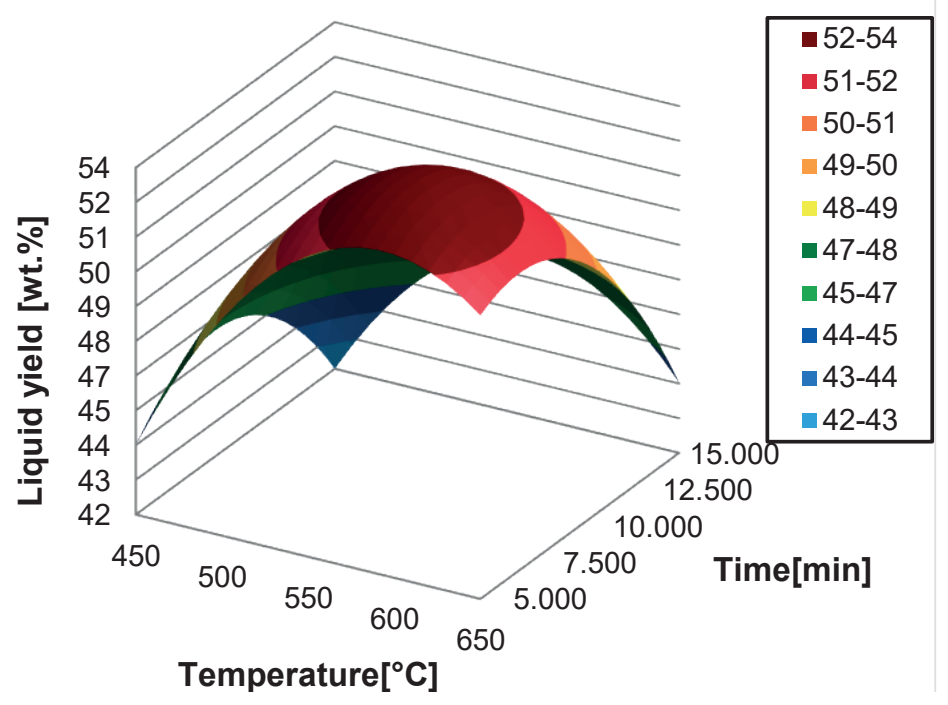

FIGURE 4: Response surface model illustrating the effect of temperature and hold time on liquid yield. 
devolatilise at lower temperatures, this explains the high char yields at lower temperatures and corresponding low liquid yields.

The liquid fraction comprised of the aqueous phase (water content) and the organic phase (oil) (Yilmaz et al., 2007). The approximate weight basis ratio of the liquid content is 1-part oil to 3-parts water (1:3). The water-soluble fraction consists of lower molecular weight substances whilst the oil consists predominantly of brown tar that contains higher molecular weight compounds. The elemental composition of the oils obtained from leather shoe waste is shown in Table 7. It should be noted that the elemental weighting is comparable to those reported from chrome-tanned leather shavings in the study by Yilmaz et al. (2007). In both studies, carbon had the highest share of the elemental composition.

The high presence of carbon from the ultimate analysis indicates a high energy density within the leather pyrolysis oil. The higher heating value (HHVs) of the liquid fraction was determined to be $33.62 \mathrm{MJ} / \mathrm{kg}$ at $550^{\circ} \mathrm{C}$. This value is significantly higher than HHVs for many other waste pyrolysis oils. For instance, Table 8 shows a comparison of the HHVs between leather oil, biomass derived pyrolysis oils and conventional oils. The HHV of the leather pyrolysis oils are higher than biomass pyrolysis oils such as softwood lignin (30.04 MJ/kg) (Ben and Ragauskas, 2011), softwood barks (25.3-26.7 MJ/kg)(Ben et al., 2019), wood and agricultural residues (16.0-19.0 MJ/kg)(Zhang et al., 2007, and Meier et al., 2013) and pine/spruce wood (16.4-17.6 MJ/kg) (Chiaramonti et al., 2007). In addition, the leather oil HHVs are higher than low-grade coal $(18 \mathrm{MJ} / \mathrm{kg}$ ) (Dinçer and Zamfirescu, 2014) but lower than conventional oils such as diesel $(45.7 \mathrm{MJ} / \mathrm{kg}$ ) and gasoline $(47.3 \mathrm{MJ} / \mathrm{kg}$ ) (Channiwala and Parikh, 2002). The HHV of the leather oil therefore indicates it has potential as an energy source or fuel.

\subsubsection{Gas yield}

In general, the gas fraction comprised a smaller share of the product yield in comparison to the solid and liquid fractions. The results indicate that, within the evaluated temperature range, the highest gas yield occurred at $550^{\circ} \mathrm{C}$ and $650^{\circ} \mathrm{C}$ during experimental runs that had a longer hold time. The lowest gas yield was observed at $450^{\circ} \mathrm{C}$ with a short hold time of 5 minutes. The low gas yield is likely attributed to the incomplete pyrolysis at this temperature, which accounts for the corresponding high solid yield. Higher process temperatures led to an increase in the gas yields at $550^{\circ} \mathrm{C}$ and $650^{\circ} \mathrm{C}$ whilst the lower process tem-

TABLE 7: Elemental composition of oil obtained from leather shoe waste.

\begin{tabular}{c|c} 
Components & Oil (wt. \%) \\
\hline Nitrogen & 8.33 \\
\hline Carbon & 69.64 \\
\hline Hydrogen & 8.57 \\
Sulfur & 1.16 \\
\hline Oxygen $^{\mathrm{b}}$ & 12.98 \\
\hline
\end{tabular}

${ }^{b}$ By difference.
TABLE 8: Comparison of HHVs for leather pyrolysis oil, other waste pyrolysis oils and conventional fuels.

\begin{tabular}{|c|c|c|}
\hline Fuel type & $\begin{array}{l}\text { HHVs } \\
\text { (MJ/kg) }\end{array}$ & Reference \\
\hline Leather oil & 33.6 & Present study \\
\hline \multicolumn{3}{|c|}{ Biomass derived pyrolysis oils } \\
\hline Softwood craft lignin & 30.04 & (Ben and Ragauskas, 2011) \\
\hline $\begin{array}{l}\text { Softwood barks (Raw pine, } \\
\text { Douglas-Fir and Pine) }\end{array}$ & $\begin{array}{l}25.3- \\
26.7\end{array}$ & (Ben et al., 2019) \\
\hline $\begin{array}{l}\text { Wood and agricultural } \\
\text { residues }\end{array}$ & $\begin{array}{l}16.0- \\
19.0\end{array}$ & (Zhang et al., 2007) \\
\hline Wood-derived bio-oil & 17.0 & (Meier et al., 2013) \\
\hline Pine/spruce wood & $\begin{array}{l}16.4- \\
17.6\end{array}$ & (Chiaramonti et al., 2007) \\
\hline Low-grade coal & 18 & (Dinçer and Zamfirescu, 2014) \\
\hline \multicolumn{3}{|l|}{ Conventional oils } \\
\hline Diesel & 45.7 & (Channiwala and Parikh, 2002) \\
\hline Gasoline & 47.3 & (Channiwala and Parikh, 2002) \\
\hline
\end{tabular}

perature of $450^{\circ} \mathrm{C}$ with a hold time of 5 minutes caused the lowest gas yield. This finding was consistent with the work of Yilmaz et al. (2007), which found similar trends of increasing gas yields and decreasing char yields as a function of higher temperatures.

A visual representation of the gas yield distribution as a function of temperature and hold time is shown in Figure 5. The increase in the gas yield can be correlated to factors including the fragmentation of the longer chained condensable volatile molecules and the sublimation of the char to permanent gases. Holding time had a less significant influence on gas yield in comparison to processing temperature. A possible explanation for this is because gas flow, heating rate and residence time of the hot condensable volatiles have a greater influence on the fragmentation of heavy molecules to light molecules in comparison to holding time. In addition, another influential factor was the fairly rapid reaction during pyrolysis which meant that even at lower hold times pyrolysis was near completion, which influenced the gas yield distribution. The response surface in Figure 5 reveals that the correlation between variables and the gas yield is less significant in comparison to trends found in the solid and liquid yields response surface. The variability in the gas yield correlating to an increase in temperature and hold time is supported by results found by Yilmaz et al. (2007). In the study by Yilmaz, a final temperature increase from 450 to $600^{\circ} \mathrm{C}$ caused an increase in gas yield from 17 to $23 \mathrm{wt}$.\% similar to this study. Similarly, Marcilla et al. (2012) observed that gas yields tended to rise with an increase in process temperature.

\subsection{Gas chromatography-mass spectrometry anal- ysis}

The results of the GC-MS analysis of leather shoe waste are presented in this section. Each of the liquid fractions from the CCD pyrolysis experiments was analyzed using the GC-MS. In total, nine liquid yields were analyzed with an initial and repeated run to ensure the replicability of findings. The general trends are discussed to provide a concise syn- 
opsis of the types of compounds present in the liquid fraction.

The results of the GC-MS analysis show a complex spectrum of liquid products from leather shoe waste. The ten major compounds identified in each of the experiments are summarized in Table 9. The main compounds identified in each of the experiments were italicized in Table 9 to emphasize their significance. The majority of the detected compounds correspond to nitrogen derivatives, which is related to the protein content of the leather shoe waste (Font et al., 1999, Sethuraman et al., 2014, and Kluska et al., 2019). The major compounds identified across GC-MS runs are 9-Octadecenamide, (Z)-; Octadecanamide, 9-Octadecenoic acid, 1,2,3-propanetriyl ester; n-Heptadecanol-1 and 13-Docosenamide. It is noteworthy that 9-Octadecenamide, (Z)-; 9-Octadecenoic acid, 1,2,3-propanetriyl ester; and 13-Docosenamide are isomers since there is a different positioning of the functional group at position 9 and 13 , respectively, instead of the normal position. It is important to take note of isomers given the differences in the arrangement of atoms within the molecule, despite the similarity in the molecular formula.

On average, the chromatograms of the liquid yield identified between 100-150 different peaks. The spectrum of compounds formed were complex, most of which were attributed to protein decomposition. As an example, Table
10 shows the list of compounds identified by the GC-MS analyzer from pyrolytic liquid yield at $550^{\circ} \mathrm{C}$ with a hold time of 10 minutes. The detected compounds in the liquid yield correspond to the chromatogram peaks depicted in Figure 6. Each peak in the chromatogram represents a compound present in the sample. The $\mathrm{x}$-axis of the chromatogram represents the retention time( $\mathrm{min})$, and the $y$-axis represents the detector response and hence the peaks of the different compounds. The motivation for presenting the results of only one of the chromatograms and tables is because there was minimal discrimination between the composition of the liquid sample yields, and a summary of the significant compounds is depicted in Table 9. The similarity index ( $\mathrm{SI}$ ) values for each peak are also presented in Table 10, according to the mass spectra libraries used. SI compares the query mass spectra with the reference mass spectra via spectrum matching and hence indicates the degree of certainty of the identified compound (Wei et al., 2014). Approximately $41 \%$ of the peaks in Table 10 present SI values greater than $90 \%$. The relatively high SI values, therefore, suggest that there was a high level of certainty amongst the identified compounds.

The main types of compounds identified in the sample were grouped based on their structure. Table 11 depicts the percentage of compounds classified according to their composition. The main group of compounds present in

TABLE 9: GC-MS chromatogram main compound list for the different pyrolytic liquid fractions.

\begin{tabular}{|c|c|c|}
\hline Pyrolytic liquid fractions & Compound name & Retention time (min) \\
\hline \multirow{10}{*}{ Yield $1\left(450^{\circ} \mathrm{C} ; 5 \mathrm{~min}\right)$} & Oleanitrile & 30.42 \\
\hline & 9-Octadecenoic acid, 1,2,3-propanetriyl ester & 31.24 \\
\hline & Octadecanamide & 31.51 \\
\hline & N-Methyldodecanamide & 31.71 \\
\hline & Cyclobutane, 3-hexyl-1,1,2-trimethyl-, cis- & 31.84 \\
\hline & Triethylene glycol monododecyl ether & 32.11 \\
\hline & 9-Octadecenamide, (Z)- & 33.04 \\
\hline & Octadecanamide & 33.23 \\
\hline & 9-Octadecenamide, N,N-dimethyl- & 33.55 \\
\hline & Pyrrolidine, 1-(6-methyl-1-oxooctadecyl)- & 35.08 \\
\hline \multirow{10}{*}{ Yield $2\left(650^{\circ} \mathrm{C} ; 5 \mathrm{~min}\right)$} & Phosphonic acid, (p-hydroxyphenyl)- & 16.32 \\
\hline & Caprolactam & 21.28 \\
\hline & 5,10-Diethoxy-2,3,7,8-tetrahydro-1H,6H-dipyrrolo & 29.31 \\
\hline & n-Heptadecanol-1 & 30.42 \\
\hline & Hexadecanamide & 31.44 \\
\hline & Coumarin-3-carbonitrile, 6-methyl- & 31.66 \\
\hline & 1,8-Diazacyclotetradecane-2,9-dione & 32.64 \\
\hline & 9-Octadecenamide, (Z)- & 33.03 \\
\hline & 9-Octadecenamide, (Z)- & 33.08 \\
\hline & Octadecanamide & 33.23 \\
\hline \multirow{10}{*}{ Yield $3\left(450^{\circ} \mathrm{C} ; 15 \mathrm{~min}\right)$} & (1H)Pyrrole-2-carbonitrile, 5-methyl- & 20.98 \\
\hline & Phenol, 2-undecyl- & 21.06 \\
\hline & 5,10-Diethoxy-2,3,7,8-tetrahydro-1H,6H-dipyrrolo & 29.24 \\
\hline & n-Heptadecanol-1 & 30.42 \\
\hline & Octadecanamide & 31.43 \\
\hline & Phenol, 4,4'-(1-methylethylidene)bis- & 31.75 \\
\hline & Benzeneacetic acid, 4-pentadecyl ester & 31.87 \\
\hline & 9-Octadecenamide, (Z)- & 33.01 \\
\hline & 9-Octadecenamide, (Z)- & 33.06 \\
\hline & Octadecanamide & 33.20 \\
\hline
\end{tabular}




\begin{tabular}{|c|c|c|}
\hline \multirow{10}{*}{ Yield $4\left(650^{\circ} \mathrm{C} ; 15 \mathrm{~min}\right)$} & Pyrrolo[1,2-a]pyrazine-1,4-dione, hexahydro- & 27.64 \\
\hline & 5,10-Diethoxy-2,3,7,8-tetrahydro-1H,6H-dipyrrolo & 29.25 \\
\hline & Oleanitrile & 30.44 \\
\hline & 6-Octadecenoic acid, (Z)- & 31.31 \\
\hline & Octadecanamide & 31.54 \\
\hline & 9-Octadecenamide, (Z)- & 33.09 \\
\hline & 13-Docosenamide, (Z)- & 33.14 \\
\hline & Octadecanamide & 33.28 \\
\hline & N-Methyldodecanamide & 33.35 \\
\hline & 9-Octadecenamide, N,N-dimethyl- & 33.57 \\
\hline \multirow{10}{*}{ Yield $5\left(550^{\circ} \mathrm{C} ; 10 \mathrm{~min}\right)$} & Aniline & 15.22 \\
\hline & Caprolactam & 21.09 \\
\hline & 1-Octadecanol & 28.38 \\
\hline & 5,10-Diethoxy-2,3,7,8-tetrahydro-1H,6H-dipyr & 29.25 \\
\hline & n-Heptadecanol-1 & 30.40 \\
\hline & Octadecanamide & 31.44 \\
\hline & Pyrrolo[1,2-a]pyrazine-1,4-dione, hexahydro-3-( & 31.87 \\
\hline & Triethylene glycol monododecyl ether & 32.09 \\
\hline & 9-Octadecenamide, (Z)- & 33.05 \\
\hline & Octadecanamide & 33.19 \\
\hline \multirow{10}{*}{ Yield $6\left(409^{\circ} \mathrm{C} ; 10 \mathrm{~min}\right)$} & Caprolactam & 20.92 \\
\hline & 5,10-Diethoxy-2,3,7,8-tetrahydro-1H,6H-dipyrrolo & 29.20 \\
\hline & 1-Hexadecanol & 30.41 \\
\hline & 9-Octadecenoic acid, 1,2,3-propanetriyl ester & 31.26 \\
\hline & Octadecanamide & 31.53 \\
\hline & 9-Octadecenamide, (Z)- & 33.04 \\
\hline & Octadecanamide & 33.23 \\
\hline & 9-Octadecenamide, N,N-dimethyl- & 33.55 \\
\hline & 9-Octadecenoic acid (Z)-, 2-butoxyethyl ester & 35.41 \\
\hline & Cholesta-3,5-diene & 40.02 \\
\hline \multirow{10}{*}{ Yield $7\left(691^{\circ} \mathrm{C} ; 10 \mathrm{~min}\right)$} & 5,10-Diethoxy-2,3,7,8-tetrahydro-1H,6H-dipyrrolo & 29.28 \\
\hline & Oleanitrile & 30.45 \\
\hline & Hexadecanenitrile & 30.62 \\
\hline & 6-Octadecenoic acid, (Z)- & 31.40 \\
\hline & Octadecanamide & 31.63 \\
\hline & N-Methyldodecanamide & 31.69 \\
\hline & 1H-Isoindole-1,3(2H)-dione, 2-(2-propynyl)- & 31.77 \\
\hline & 13-Docosenamide, (Z)- & 33.16 \\
\hline & Octadecanamide & 33.32 \\
\hline & 9-Octadecenamide, N,N-dimethyl- & 33.58 \\
\hline \multirow{10}{*}{ Yield $8\left(550^{\circ} \mathrm{C} ; 17 \mathrm{~min}\right)$} & Oleanitrile & 30.39 \\
\hline & Octadecanamide & 30.82 \\
\hline & N-Methyldodecanamide & 31.01 \\
\hline & 6-Octadecenoic acid, (Z)- & 31.33 \\
\hline & Octadecanamide & 31.56 \\
\hline & N-Methyldodecanamide & 31.64 \\
\hline & D-Mannohexadecane-1,2,3,4,5-pentaol & 31.70 \\
\hline & Cyclopropanecarboxylic acid,pentadecyl ester & 32.03 \\
\hline & 9-Octadecenamide, (Z)- & 32.87 \\
\hline & 13-Docosenamide, (Z)- & 33.03 \\
\hline \multirow{10}{*}{ Yield $9\left(550^{\circ} \mathrm{C} ; 3 \mathrm{~min}\right)$} & Phenol, 2-methyl- & 17.33 \\
\hline & 1H-Indene, 1-methylene- & 19.56 \\
\hline & Caprolactam & 21.08 \\
\hline & Naphthalene, 2-methyl- & 21.57 \\
\hline & 5,10-Diethoxy-2,3,7,8-tetrahydro-1H,6H-dipyrrolo & 29.20 \\
\hline & n-Heptadecanol-1 & 30.34 \\
\hline & Octadecanamide & 31.37 \\
\hline & 9-Octadecenamide, (Z)- & 32.93 \\
\hline & 9-Octadecenamide, (Z)- & 32.98 \\
\hline & Octadecanamide & 33.21 \\
\hline
\end{tabular}


TABLE 10: Peak Report TIC.

\begin{tabular}{|c|c|c|c|c|c|}
\hline $\begin{array}{c}\text { Peak } \\
\#\end{array}$ & $\begin{array}{c}\mathbf{R} \\
\text { Time }\end{array}$ & $\begin{array}{c}\text { Area } \\
\%\end{array}$ & Formula & $\begin{array}{c}\text { A/H } \\
\text { Name }\end{array}$ & $\begin{array}{l}\text { SI } \\
(\%)\end{array}$ \\
\hline 1 & 11.767 & 0.20 & $\mathrm{C} 6 \mathrm{H} 11 \mathrm{~N}$ & Hexanenitrile & 95 \\
\hline 2 & 13.692 & 0.21 & $\mathrm{C} 6 \mathrm{H} 9 \mathrm{~N}$ & 1H-Pyrrole, 2,5-dimethyl- & 92 \\
\hline 3 & 15.224 & 1.79 & $\mathrm{C} 6 \mathrm{H} 7 \mathrm{~N}$ & Aniline & 96 \\
\hline 4 & 15.380 & 0.64 & $\mathrm{C} 7 \mathrm{H} 5 \mathrm{~N}$ & Benzonitrile & 95 \\
\hline 5 & 15.870 & 0.61 & $\mathrm{C} 6 \mathrm{H} 704 \mathrm{P}$ & Phosphonic acid, (p-hydroxyphenyl)- & 96 \\
\hline 6 & 15.932 & 1.62 & $\mathrm{C} 6 \mathrm{H} 6 \mathrm{O}$ & Phenol & 96 \\
\hline 7 & 16.000 & 0.34 & $\mathrm{C} 7 \mathrm{H} 11 \mathrm{~N}$ & 1H-Pyrrole, 2-ethyl-4-methyl- & 88 \\
\hline 8 & 16.181 & 0.50 & $\mathrm{C} 5 \mathrm{H} 6 \mathrm{~N} 2$ & 2-Aminopyridine & 95 \\
\hline 9 & 16.458 & 0.92 & $\mathrm{C} 10 \mathrm{H} 16$ & D-Limonene & 95 \\
\hline 10 & 16.560 & 0.22 & $\mathrm{C} 8 \mathrm{H} 180$ & 1-Hexanol, 2-ethyl- & 88 \\
\hline 11 & 16.786 & 0.14 & $\mathrm{C} 9 \mathrm{H} 9 \mathrm{Cl}$ & 1H-Indene, 1-chloro-2,3-dihydro- & 95 \\
\hline 12 & 17.369 & 1.15 & $\mathrm{C} 7 \mathrm{H} 8 \mathrm{O}$ & Phenol, 2-methyl- & 97 \\
\hline 13 & 17.415 & 0.27 & C7H9N & p-Aminotoluene & 92 \\
\hline 14 & 17.476 & 0.40 & $\mathrm{C} 7 \mathrm{H} 9 \mathrm{~N}$ & p-Aminotoluene & 98 \\
\hline 15 & 17.856 & 1.04 & C7H8O & p-Cresol & 95 \\
\hline 16 & 17.935 & 0.51 & C6H8N2 & 2-Pyridinamine, 3-methyl- & 90 \\
\hline 17 & 18.067 & 0.36 & $\mathrm{C} 8 \mathrm{H} 7 \mathrm{~N}$ & Benzonitrile, 4-methyl- & 96 \\
\hline 18 & 18.240 & 0.24 & $\mathrm{C} 8 \mathrm{H} 100$ & Phenol, 2,5-dimethyl- & 92 \\
\hline 19 & 18.560 & 0.17 & $\mathrm{C} 7 \mathrm{H} 12 \mathrm{O}$ & 1-Heptyn-4-ol & 74 \\
\hline 20 & 18.689 & 0.24 & $\mathrm{C} 8 \mathrm{H} 18 \mathrm{O} 2$ & 1-Butanol, 4-butoxy- & 92 \\
\hline 21 & 18.725 & 0.18 & $\mathrm{C} 8 \mathrm{H} 7 \mathrm{~N}$ & Benzyl nitrile & 92 \\
\hline 22 & 19.095 & 0.32 & $\mathrm{C} 8 \mathrm{H} 100$ & Phenol, 2,4-dimethyl- & 89 \\
\hline 23 & 19.521 & 0.71 & C7H10N2 & Pyridine, 2-aminomethyl-6-methyl- & 70 \\
\hline 24 & 19.581 & 0.53 & $\mathrm{C} 10 \mathrm{H} 8$ & Naphthalene & 98 \\
\hline 25 & 19.695 & 0.43 & $\mathrm{C} 9 \mathrm{H} 17 \mathrm{NO}$ & Octane, 1-isocyanato- & 78 \\
\hline 26 & 20.414 & 0.33 & $\mathrm{C9H9N}$ & Benzenepropanenitrile & 96 \\
\hline 27 & 20.459 & 0.18 & $\mathrm{C} 8 \mathrm{H} 10 \mathrm{Cl} 2$ & Cyclohexene, 1-chloro-4-(1-chloroethenyl)- & 88 \\
\hline 28 & 20.684 & 0.32 & $\mathrm{C} 9 \mathrm{H} 12 \mathrm{O}$ & Phenol, 3-(1-methylethyl)- & 92 \\
\hline 29 & 21.088 & 7.76 & $\mathrm{C} 6 \mathrm{H} 11 \mathrm{NO}$ & Caprolactam & 94 \\
\hline 30 & 21.362 & 0.26 & $\mathrm{C} 11 \mathrm{H} 10$ & Naphthalene, 2-methyl- & 90 \\
\hline 31 & 21.604 & 0.65 & $\mathrm{C} 11 \mathrm{H} 10$ & Naphthalene, 2-methyl- & 91 \\
\hline 32 & 22.017 & 0.72 & C5H8N2O2 & 2,4-Imidazolidinedione, 5,5-dimethyl- & 69 \\
\hline 33 & 22.640 & 0.20 & $\mathrm{C} 9 \mathrm{H} 16 \mathrm{O} 2$ & Bicyclo[3.3.1]nonane-2,9-diol, exo-anti- & 67 \\
\hline 34 & 22.731 & 0.12 & $\mathrm{C} 9 \mathrm{H} 9 \mathrm{~N}$ & 1H-Indole, 6-methyl- & 94 \\
\hline 35 & 23.692 & 0.30 & $\mathrm{C} 12 \mathrm{H} 260$ & 1-Dodecanol & 94 \\
\hline 36 & 23.811 & 0.15 & $\mathrm{C} 12 \mathrm{H} 24 \mathrm{BNO}$ & (hexahydro-2H-azepin-2-onato-N1,02)bis(1-methylethyl)-, (t-4)- & 73 \\
\hline 37 & 25.055 & 0.20 & $\mathrm{C} 5 \mathrm{H} 4 \mathrm{~N} 40$ & 1H-Imidazo(4,5-d)pyridazin-7-ol & 78 \\
\hline 38 & 25.400 & 0.37 & $\mathrm{C} 8 \mathrm{H} 1802$ & 1-Butanol, 4-butoxy- & 80 \\
\hline 39 & 25.497 & 0.12 & C8H7NS2 & Benzothiazole, 2-(methylthio)- & 85 \\
\hline 40 & 26.160 & 0.44 & $\mathrm{C} 16 \mathrm{H} 30 \mathrm{Cl} 2 \mathrm{O} 2$ & Dichloroacetic acid, tetradecyl ester & 81 \\
\hline 41 & 26.603 & 0.18 & $\mathrm{C} 14 \mathrm{H} 30 \mathrm{O} 2$ & Ethanol, 2-(dodecyloxy)- & 91 \\
\hline 42 & 26.694 & 1.28 & $\mathrm{C} 11 \mathrm{H} 10 \mathrm{~N} 20$ & Furaldehyde phenylhydrazone & 75 \\
\hline 43 & 26.894 & 0.95 & $\mathrm{C} 10 \mathrm{H} 14 \mathrm{~N} 2 \mathrm{O} 3$ & 3-Methyl-1,4-diazabicyclo[4.3.0]nonan-2,5-dione, N-acetyl- & 84 \\
\hline 44 & 26.965 & 0.34 & $\mathrm{C} 10 \mathrm{H} 140$ & Benzene, (1-methylpropoxy)- & 64 \\
\hline 45 & 27.110 & 0.12 & $\mathrm{C} 10 \mathrm{H} 8 \mathrm{~N} 20$ & 3-Phenoxypyridazine & 77 \\
\hline 46 & 27.210 & 0.53 & $\mathrm{C} 10 \mathrm{H} 14 \mathrm{~N} 2 \mathrm{O} 3$ & 3-Methyl-1,4-diazabicyclo[4.3.0]nonan-2,5-dione, N-acetyl- & 72 \\
\hline 47 & 27.403 & 0.32 & C17H31F302 & Trifluoroacetic acid, pentadecyl ester & 91 \\
\hline 48 & 27.470 & 0.47 & $\mathrm{C} 14 \mathrm{H} 29 \mathrm{Br}$ & 2-Bromotetradecane & 77 \\
\hline 49 & 27.560 & 1.07 & $\mathrm{C} 11 \mathrm{H} 240$ & Undecanol-4 & 77 \\
\hline 50 & 27.620 & 1.36 & $\mathrm{C} 7 \mathrm{H} 10 \mathrm{~N} 2 \mathrm{O} 2$ & Pyrrolo[1,2-a]pyrazine-1,4-dione, hexahydro- & 87 \\
\hline 51 & 27.780 & 0.20 & $\mathrm{C} 15 \mathrm{H} 22 \mathrm{~N} 2 \mathrm{O} 4$ & 2,6-Piperidinedione, 1,1'-(1,5-pentanediyl)bis- & 73 \\
\hline 52 & 28.181 & 0.11 & $\mathrm{C} 16 \mathrm{H} 22 \mathrm{O} 4$ & 1,2-Benzenedicarboxylic acid, bis(2-methylpropyl) ester & 89 \\
\hline 53 & 28.377 & 2.42 & $\mathrm{C} 18 \mathrm{H} 380$ & 1-Octadecanol & 87 \\
\hline 54 & 28.572 & 0.31 & $\mathrm{C} 15 \mathrm{H} 29 \mathrm{~N}$ & Pentadecanenitrile & 94 \\
\hline 55 & 28.941 & 0.47 & $\mathrm{C} 8 \mathrm{H} 12 \mathrm{O} 3$ & 6-Hydroxy-9-oxa-bicyclo[3.3.1]nonan-3-one & 69 \\
\hline 56 & 29.145 & 0.41 & $\mathrm{C} 11 \mathrm{H} 18 \mathrm{~N} 2 \mathrm{O} 2$ & Pyrrolo[1,2-a]pyrazine-1,4-dione, hexahydro-3-(2-methylpropyl)- & 75 \\
\hline 57 & 29.246 & 3.37 & $\mathrm{C} 14 \mathrm{H} 22 \mathrm{~N} 2 \mathrm{O} 2$ & 5,10-Diethoxy-2,3,7,8-tetrahydro-1H,6H-dipyrrolo[1,2-a:1',2'-d]pyrazine & 93 \\
\hline
\end{tabular}




\begin{tabular}{|c|c|c|c|c|c|}
\hline 58 & 29.346 & 1.26 & $\mathrm{C} 11 \mathrm{H} 18 \mathrm{~N} 2 \mathrm{O} 2$ & Pyrrolo[1,2-a]pyrazine-1,4-dione, hexahydro-3-(2-methylpropyl)- & 86 \\
\hline 59 & 29.517 & 0.20 & $\mathrm{C} 16 \mathrm{H} 34 \mathrm{O} 3$ & Diethylene glycol monododecyl ether & 90 \\
\hline 60 & 30.105 & 0.28 & $\mathrm{C} 11 \mathrm{H} 1802$ & 2-Propanone, 1-(1-cyclohexen-1-yl)-3-ethoxy- & 59 \\
\hline 61 & 30.174 & 0.21 & $\mathrm{C} 18 \mathrm{H} 360$ & 9-Octadecen-1-ol, (Z)- & 96 \\
\hline 62 & 30.403 & 3.16 & $\mathrm{C} 17 \mathrm{H} 360$ & n-Heptadecanol-1 & 92 \\
\hline 63 & 30.507 & 0.25 & $\mathrm{C} 17 \mathrm{H} 32 \mathrm{O} 2$ & 7-Hexadecenoic acid, methyl ester, (Z)- & 73 \\
\hline 64 & 30.595 & 0.36 & $\mathrm{C} 14 \mathrm{H} 27 \mathrm{~N}$ & Tetradecanenitrile & 85 \\
\hline 65 & 30.677 & 0.70 & C7H9N5O & 1-[3-Pyridyl]-3-amidine urea & 65 \\
\hline 66 & 30.793 & 0.12 & $\mathrm{C} 22 \mathrm{H} 46 \mathrm{O} 2$ & Ethanol, 2-(eicosyloxy)- & 89 \\
\hline 67 & 31.011 & 0.81 & C7H9NO2 & Ethyl 2-cyanocrotonate & 75 \\
\hline 68 & 31.095 & 0.63 & $\mathrm{C} 13 \mathrm{H} 14 \mathrm{~N} 2$ & Benzenamine, 4,4'-methylenebis- & 88 \\
\hline 69 & 31.145 & 1.53 & $\mathrm{C} 18 \mathrm{H} 38 \mathrm{~S}$ & 1-Octadecanethiol & 87 \\
\hline 70 & 31.439 & 8.69 & C18H37NO & Octadecanamide & 90 \\
\hline 71 & 31.647 & 1.14 & $\mathrm{C} 13 \mathrm{H} 27 \mathrm{NO}$ & N-Methyldodecanamide & 81 \\
\hline 72 & 31.741 & 2.07 & $\mathrm{C} 15 \mathrm{H} 16 \mathrm{O} 2$ & Phenol, 4,4'-(1-methylethylidene)bis- & 75 \\
\hline 73 & 31.869 & 2.71 & $\mathrm{C} 11 \mathrm{H} 18 \mathrm{~N} 2 \mathrm{O} 2$ & Pyrrolo[1,2-a]pyrazine-1,4-dione, hexahydro-3-(2-methylpropyl)- & 62 \\
\hline 74 & 32.093 & 2.14 & $\mathrm{C} 18 \mathrm{H} 3804$ & Triethylene glycol monododecyl ether & 88 \\
\hline 75 & 32.265 & 1.33 & $\mathrm{C} 26 \mathrm{H} 52$ & Cyclohexane, 1,4-didecyl- & 76 \\
\hline 76 & 32.405 & 1.11 & $\mathrm{C} 19 \mathrm{H} 2802$ & m-Toluic acid, undec-2-enyl ester & 77 \\
\hline 77 & 32.525 & 1.25 & $\mathrm{C} 12 \mathrm{H} 22 \mathrm{~N} 2 \mathrm{O} 2$ & 1,8-Diazacyclotetradecane-2,9-dione & 90 \\
\hline 78 & 32.625 & 0.73 & $\mathrm{C} 22 \mathrm{H} 46 \mathrm{O} 2$ & Ethanol, 2-(eicosyloxy)- & 91 \\
\hline 79 & 32.725 & 0.81 & $\mathrm{C} 18 \mathrm{H} 18 \mathrm{O} 2$ & 4,4'-Diallyloxydiphenyl & 55 \\
\hline 80 & 33.050 & 11.86 & $\mathrm{C} 18 \mathrm{H} 35 \mathrm{NO}$ & 9-Octadecenamide, (Z)- & 88 \\
\hline 81 & 33.194 & 3.84 & $\mathrm{C} 18 \mathrm{H} 37 \mathrm{NO}$ & Octadecanamide & 95 \\
\hline 82 & 33.370 & 1.17 & $\mathrm{C} 14 \mathrm{H} 16 \mathrm{~N} 2 \mathrm{O} 2$ & Pyrrolo[1,2-a]pyrazine-1,4-dione, hexahydro-3-(phenylmethyl)- & 79 \\
\hline 83 & 33.445 & 0.57 & $\mathrm{C} 13 \mathrm{H} 27 \mathrm{NO}$ & N-Methyldodecanamide & 88 \\
\hline 84 & 33.625 & 1.27 & $\mathrm{C} 2 \mathrm{OH} 39 \mathrm{NO}$ & 9-Octadecenamide, N,N-dimethyl- & 77 \\
\hline 85 & 33.790 & 0.56 & $\mathrm{C} 22 \mathrm{H} 38 \mathrm{O} 2$ & Cyclopropaneoctanoic acid, 2-[[2-[(2-ethylcyclopropyl)methyl]cyclopropyl]methyl]-, methyl ester & 78 \\
\hline 86 & 33.874 & 0.56 & $\mathrm{C} 18 \mathrm{H} 3804$ & Triethylene glycol monododecyl ether & 89 \\
\hline 87 & 34.051 & 0.74 & $\mathrm{C} 24 \mathrm{H} 500$ & $\mathrm{n}$-Tetracosanol-1 & 83 \\
\hline 88 & 34.574 & 0.87 & $\mathrm{C} 2 \mathrm{OH} 42 \mathrm{O} 5$ & Tetraethylene glycol monododecyl ether & 91 \\
\hline 89 & 34.721 & 1.01 & $\mathrm{C} 10 \mathrm{H} 1803$ & 1,3-Dioxolan-4-one, 2-(1,1-dimethylethyl)-5-(1-methylethyl)-, (2S-cis)- & 75 \\
\hline 90 & 35.292 & 0.44 & $\mathrm{C} 16 \mathrm{H} 3403$ & Diethylene glycol monododecyl ether & 87 \\
\hline 91 & 36.075 & 0.21 & $\mathrm{C} 36 \mathrm{H} 58$ & $15,17,19,21-$ Hexatriacontatetrayne & 57 \\
\hline 92 & 36.154 & 0.43 & $\mathrm{C} 18 \mathrm{H} 3804$ & Triethylene glycol monododecyl ether & 90 \\
\hline 93 & 36.838 & 0.43 & $\mathrm{C} 10 \mathrm{H} 1803$ & 1,3-Dioxolan-4-one, 2-(1,1-dimethylethyl)-5-(1-methylethyl)-, (2S-cis)- & 75 \\
\hline 94 & 36.933 & 0.64 & $\mathrm{C} 18 \mathrm{H} 3407$ & 2,2'-(2,2'-Oxybis(ethane-2,1-diyl)bis(oxy))bis(ethane-2,1-diyl) dipentanoate & 75 \\
\hline 95 & 37.136 & 0.30 & $\mathrm{C} 2 \mathrm{OH} 42 \mathrm{O} 5$ & Tetraethylene glycol monododecyl ether & 88 \\
\hline 96 & 37.636 & 0.31 & $\mathrm{C} 22 \mathrm{H} 39 \mathrm{NO}$ & Pyrrolidine, 1-(1-oxo-10-octadecynyl)- & 66 \\
\hline 97 & 38.272 & 0.57 & $\mathrm{C} 26 \mathrm{H} 5408$ & Heptaethylene glycol monododecyl ether & 92 \\
\hline 98 & 39.542 & 0.54 & $\mathrm{C} 18 \mathrm{H} 3804$ & Triethylene glycol monododecyl ether & 88 \\
\hline 99 & 39.835 & 0.41 & $\mathrm{C} 30 \mathrm{H} 61 \mathrm{Br}$ & Triacontane, 1-bromo- & 72 \\
\hline 100 & 39.985 & 1.02 & $\mathrm{C} 27 \mathrm{H} 44$ & Cholesta-3,5-diene & 94 \\
\hline
\end{tabular}

the liquid fraction are compounds containing nitrogen or nitrogen and oxygen atoms in their structure. This finding is consistent with studies by Marcilla et al. (2012) and Kluska et al. (2019), which also identified nitrogenated compounds as the main group of compounds from the analysis of liquid fraction from leather pyrolysis. The percentage of nitrogenated compounds in this study were, however, significantly lower in comparison to the study by Marcilla. The justification for this difference is because this study utilized slow pyrolysis in comparison to fast pyrolysis in the study by Marcilla et al. (2012). This is an important factor to consider as it influences the liquid product composition. The second major group found in the liquid fraction was oxygenated compounds (containing ketones, aldehydes, alcohols, and acids), followed by aromatics, phenols, alkanes, and alkenes, and lastly, sulfur-containing compounds. The compound distribution found in this study exhibit similarities to those reported by Fang et al. (2018).

Based on the composition of the liquid fraction, it would be useful for the following applications. The abundance of $\mathrm{NH}_{2}$ groups present in the liquid fraction makes it potentially valuable for the production of fertilizers (Marcilla et al., 2012). According to Yilmaz et al. (2007), the liquid yield can additionally be useful as a chemical feedstock or a fuel after retreatments such as hydrogenation, Fischer-Tropsch synthesis, or stream cracking. Some of the main compounds from the liquid chemistries including Octadecanamide and 13-Docosenamide have useful applications as adhesives and sealant chemicals, anti-adhesive agents, as well as lubricants and or surface agents (NCBI, 2020a., and $\mathrm{NCBI}, 2020 \mathrm{~b}$ ). According to Getachew et al. (2016), oleamides may present industrial applications such as lubricants, 
TABLE 11: Liquid yield compound classification.

\begin{tabular}{|c|c|}
\hline Classification type & Percentages of compounds (\%) \\
\hline $\mathrm{N}$ or $\mathrm{N} / \mathrm{O}$ compounds & 40 \\
\hline O compounds & 35 \\
\hline Alkanes and alkenes & 9 \\
\hline Aromatics & 6 \\
\hline Phenols & 6 \\
\hline \multirow[t]{2}{*}{ S compounds } & 2 \\
\hline & 100 \\
\hline
\end{tabular}

$(N$ or $N / O=$ compounds containing $N$ or $N$ and $0 ; 0$ compounds $=$ com pounds containing oxygen; alkanes and alkenes=hydrogen and carbon compounds; aromatics = aromatics; phenols = phenol and its derivates; $S$ compounds =compounds containing sulfur)

corrosion inhibitors and slip agents. Specific compounds, such as pyrrole and its derivatives, can be useful as intermediates in the synthesis of pharmaceuticals, perfumes, agrochemicals, and dyes (Marcilla et al., 2012, and Kaur et al., 2017). To achieve the applications for leather footwear pyrolysis products it is necessary to consider that processing would be required in order to improve the product quality through purifying, refining and upgrading the products.

A limitation of pyrolysis in this study, and in general, is that it relies on an external energy supply to reach its processing temperatures, which is often derived from non-renewable sources. Future leather pyrolysis studies should therefore consider solar assisted pyrolysis to overcome this obstacle by prioritizing the utilization of solar energy for thermochemical processing (Morales et al., 2014, and Weldekidan et al., 2018).

\section{CONCLUSIONS}

This study investigated whether leather from post-consumer footwear could be pyrolyzed using gram-scale (fixed-bed) and microgram-scale (TGA) pyrolysis reactors. The distribution of the product fractions proved that leather footwear pyrolysis was viable under the given conditions. It was shown through an examination of pyrolysis product distribution and characterization that leather footwear has waste recovery potential, hence contributing to the overall aim of the study.

The results of this study showed that pyrolysis temperature has a significant effect on the product yields. According to the results obtained, the liquid yield was maximized within the temperature range of $550-650^{\circ} \mathrm{C}(\mathrm{Max}=54 \mathrm{wt} . \%)$. The solid yield decreased substantially from $43 \mathrm{wt} . \%$ to 25 wt.\% with an increase in the reactor temperature. The solid yield indicated the completion of leather footwear pyrolysis at $650^{\circ} \mathrm{C}$ since a constant value of approximately $25 \mathrm{wt} . \%$ was reached. This was verified since the solid yield remaining corresponded to the fixed carbon and ash proportions characterized in the leather sample. There was a general increase of gas yields as a function of higher temperatures and longer residence times, explained by decreasing char yields in the leather sample.

The pyrolysis product yields were characterized, and the char yield revealed that it may be suitable as a solid fuel due to its high calorific value $(25.55 \mathrm{MJ} / \mathrm{kg})$. A wide distribution of pyrolytic compounds were presented in this study, with nitrogenated derivatives forming the major group from the liquid yield. Based on the composition of the liquid yields, potential applications include use in the production of fertilizers, use as a chemical feedstock and use in the pharmaceutical industry. In addition, some of the main compounds found present potential industrial applications including use as adhesives, sealant chemicals, anti-adhesive agents, lubricants, and surface agents. Due to the composition of the pyrolysis product yields, however, it is necessary to consider retreatment before application to remove impurities. The pyrolysis oil presented a gross calorific value higher than biomass derived pyrolysis oils and low-grade coal. This indicated its potential as an energy source or fuel. It can therefore be concluded that the leather pyrolysis oils present a more valuable source of energy than some biomass pyrolysis oils.

Future work should investigate the quantitative aspect of the compounds present in the pyrolysis yields. This would further substantiate the potential for reuse applications and the viability of recovering these materials from leather footwear in practice.

\section{AKNOWLED GEMENTS}

The financial assistance of the National Research Foundation (NRF) towards this research is hereby acknowledged. Opinions expressed and conclusions arrived at, are those of the authors and are not necessarily attributed to the NRF. The funding source did not play a role in the study design; in the collection, analysis, and interpretation of data; in the writing of the report; and in the decision to submit the article for publication. Furthermore, the funding source did not have any direct involvement in the compilation of the manuscript.

\section{REFERENCES}

Al Arni, S. (2018). Comparison of slow and fast pyrolysis for converting biomass into fuel. Renewable Energy, 124, 197-201. https://doi. org/10.1016/j.renene.2017.04.060

Albers, K., Canepa, P., \& Miller, J. (2008). Analyzing the Environmental Impacts of Simple Shoes (Masters). University of Santa Barbara.

Arabiourrutia, M., Lopez, G., Artetxe, M., Alvarez, J., Bilbao, J., \& Olazar, M. (2020). Waste tyre valorization by catalytic pyrolysis - A review. Renewable And Sustainable Energy Reviews, 129, 109932. https:// doi.org/10.1016/j.rser.2020.109932

Aylón, E., Fernández-Colino, A., Murillo, R., Navarro, M., García, T., \& Mastral, A. (2010). Valorisation of waste tyre by pyrolysis in a moving bed reactor. Waste Management, 30(7), 1220-1224. https:// doi.org/10.1016/j.wasman.2009.10.001

Aziz, M., Rahman, M., \& Molla, H. (2018). Design, fabrication and performance test of a fixed bed batch type pyrolysis plant with scrap tire in Bangladesh. Journal Of Radiation Research And Applied Sciences, 11(4), 311-316. https://doi.org/10.1016/j.jrras.2018.05.001

He, B.J., Zhang, Y., Yin, Y., Funk, T.L., \& Riskowski, G.L. (2000). OPERATING TEMPERATURE AND RETENTION TIME EFFECTS ON THE THERMOCHEMICAL CONVERSION PROCESS OF SWINE MANURE. Transactions Of The ASAE, 43(6), 1821-1825. https://doi. org/10.13031/2013.3086

Baniasadi, M., Tugnoli, A., Conti, R., Torri, C., Fabbri, D., \& Cozzani, V. (2016). Waste to energy valorization of poultry litter by slow pyrolysis. Renewable Energy, 90, 458-468. https://doi.org/10.1016/j. renene.2016.01.018 
Bañón, E., Marcilla, A., García, A., Martínez, P., \& León, M. (2016). Kinetic model of the thermal pyrolysis of chrome tanned leather treated with $\mathrm{NaOH}$ under different conditions using thermogravimetric analysis. Waste Management, 48, 285-299. https://doi. org/10.1016/j.wasman.2015.10.012

Basu, P. (2018). Biomass gasification, pyrolysis and torrefaction (3rd ed., pp. 479-495). Elsevier.

Ben, H., \& Ragauskas, A. (2011). NMR Characterization of Pyrolysis Oils from Kraft Lignin. Energy \& Fuels, 25(5), 2322-2332. https:// doi.org/10.1021/ef2001162

Ben, H., Wu, F., Wu, Z., Han, G., Jiang, W., \& Ragauskas, A. (2019). A Comprehensive Characterization of Pyrolysis Oil from Softwood Barks. Polymers, 11(9), 1387. https://doi.org/10.3390/polym11091387

Channiwala, S., \& Parikh, P. (2002). A unified correlation for estimating HHV of solid, liquid and gaseous fuels. Fuel, 81(8), 1051-1063. https://doi.org/10.1016/s0016-2361(01)00131-4

Chiaramonti, D., Oasmaa, A., \& Solantausta, Y. (2007). Power generation using fast pyrolysis liquids from biomass. Renewable And Sustainable Energy Reviews, 11(6), 1056-1086. https://doi.org/10.1016/j. rser.2005.07.008

Chrobot, P., Faist, M., Gustavus, L., Martin, A., Stamm, A., Zah, R., \& Zollinge, M. (2018). Measuring fashion: Environmental impact of the global apparel and footwear industries study. Full report and methodological considerations. Lausanne: Quantis.

Chowdhury, Z., Ahmed, T., Antunes, P., \& Paul, H. (2018). Environmental Life Cycle Assessment of Leather Processing Industry: A Case Study of Bangladesh. Journal- Society Of Leather Technologists And Chemists, 102. Retrieved 11 November 2020, from.

Czajczyńska, D., Nannou, T., Anguilano, L., Krzyżyńska, R., Ghazal, H., Spencer, N., \& Jouhara, H. (2017). Potentials of pyrolysis processes in the waste management sector. Energy Procedia, 123, 387394. https://doi.org/10.1016/j.egypro.2017.07.275

Demirbas, A. (2016). Calculation of higher heating values of fatty acids. Energy Sources, Part A: Recovery, Utilization, And Environmental Effects, 38(18), 2693-2697. https://doi.org/10.1080/15567036.20 15.1115924

Dinçer, I., \& Zamfirescu, C. (2014). Advanced power generation systems. Elsevier.

Dhyani, V., \& Bhaskar, T. (2018). A comprehensive review on the pyrolysis of lignocellulosic biomass. Renewable Energy, 129, 695-716. https://doi.org/10.1016/j.renene.2017.04.035

Fang, C., Jiang, X., Lv, G., Yan, J., Lin, X., Song, H., \& Cao, J. (2018). Pyrolysis characteristics and $\mathrm{Cr}$ speciation of chrome-tanned leather shavings: influence of pyrolysis temperature. Energy Sources, Part A: Recovery, Utilization, And Environmental Effects, 41(7), 881-891. https://doi.org/10.1080/15567036.2018.1520366

Filho, A., Lange, L., de Melo, G., \& Praes, G. (2016). Pyrolysis of chromium rich tanning industrial wastes and utilization of carbonized wastes in metallurgical process. Waste Management, 48, 448-456. https://doi.org/10.1016/j.wasman.2015.11.046

Font, R., Caballero, J., Esperanza, M., \& Fullana, A. (1999). Pyrolytic products from tannery wastes. Journal Of Analytical And Applied Pyrolysis, 49(1-2), 243-256. https://doi.org/10.1016/s01652370(98)00117-x

Fyvie, E. (2018). Trash revolution: Breaking the Waste Cycle. Kids Can Press, Limited.

Gao, N., Quan, C., Liu, B., Li, Z., Wu, C., \& Li, A. (2017). Continuous Pyrolysis of Sewage Sludge in a Screw-Feeding Reactor: Products Characterization and Ecological Risk Assessment of Heavy Metals. Energy \& Fuels, 31(5), 5063-5072. https://doi.org/10.1021/ acs.energyfuels.6b03112

Getachew, P., Getachew, M., Joo, J., Choi, Y., Hwang, D., \& Hong, Y. (2016). The slip agents oleamide and erucamide reduce biofouling by marine benthic organisms (diatoms, biofilms and abalones). Toxicology And Environmental Health Sciences, 8(5), 341-348. https://doi.org/10.1007/s13530-016-0295-8

Godinho, M., Birriel, E., Marcilio, N., Masotti, L., Martins, C., \& Wenzel, B. (2011). High-temperature corrosion during the thermal treatment of footwear leather wastes. Fuel Processing Technology, 92(5) 1019-1025. https://doi.org/10.1016/j.fuproc.2010.12.025

Gottfridsson, M., \& Zhang, Y. (2015). Environmental impacts of shoe consumption: Combining product flow analysis with an LCA mode for Sweden (Masters). Chalmers University of technology.

Guda, V., Steele, P., Penmetsa, V., \& Li, Q. (2015). Fast Pyrolysis of Biomass: Recent Advances in Fast Pyrolysis Technology. In A. Pandey, M. Stöcker, T. Bhaskar \& R. Sukumaran, Recent Advances in Thermochemical Conversion of Biomass (pp. 177-211). Elsevier. Retrieved 12 November 2020, from.
He, X., Liu, Z., Niu, W., Yang, L., Zhou, T., \& Qin, D. et al. (2018). Effects of pyrolysis temperature on the physicochemical properties of gas and biochar obtained from pyrolysis of crop residues. Energy, 143, 746-756. https://doi.org/10.1016/j.energy.2017.11.062

Hedberg, Y., Lidén, C., \& Odnevall Wallinder, I. (2015). Chromium released from leather - I: exposure conditions that govern the release of chromium( III ) and chromium( VI ). Contact Dermatitis, 72(4), 206-215. https://doi.org/10.1111/cod.12329

Hirvonen, P. (2017). The potential of waste tyre and waste plastics pyrolysis in Southern Savonia region (Masters). Lappeenranta University of Technology.

Islam, M., Islam, M., Mustafi, N., Rahim, M., \& Haniu, H. (2013). Thermal Recycling of Solid Tire Wastes for Alternative Liquid Fuel: The First Commercial Step in Bangladesh. Procedia Engineering, 56, 573582. https://doi.org/10.1016/j.proeng.2013.03.162

Januszewicz, K., Klein, M., Klugmann-Radziemska, E., \& Kardas, D. (2016). Thermogravimetric analysis/pyrolysis of used tyres and waste rubber. Physicochemical Problems Of Mineral Processing, 53, 802-811. https://doi.org/doi:10.1515/cpe-2017-0028.

Jo, J., Kim, S., Shim, J., Lee, Y., \& Yoo, Y. (2017). Pyrolysis Characteristics and Kinetics of Food Wastes. Energies, 10(8), 1191. https:// doi.org/10.3390/en10081191

Joseph, K., \& Nithya, N. (2009). Material flows in the life cycle of leather. Journal Of Cleaner Production, 17(7), 676-682. https://doi. org/10.1016/j.jclepro.2008.11.018

Kaur, R., Rani, V., Abbot, V., Kapoor, Y., Konar, D., \& Kumar, K. (2017) Recent synthetic and medicinal perspectives of pyrroles: An overview. Journal Of Pharmaceutical Chemistry \& Chemical Science, 1 , 17-32. Retrieved 12 November 2020, from.

Kluska, J., Ochnio, M., Kardaś, D., \& Heda, Ł. (2019). The influence of temperature on the physicochemical properties of products of pyrolysis of leather-tannery waste. Waste Management, 88, 248-256. https://doi.org/10.1016/j.wasman.2019.03.046

Kolomaznik, K., Adamek, M., Andel, I., \& Uhlirova, M. (2008). Leather waste-Potential threat to human health, and a new technology of its treatment. Journal Of Hazardous Materials, 160(2-3), 514-520. https://doi.org/10.1016/j.jhazmat.2008.03.070

Lopez, G., Alvarez, J., Amutio, M., Mkhize, N., Danon, B., \& van der Gryp, P. et al. (2017). Waste truck-tyre processing by flash pyrolysis in a conical spouted bed reactor. Energy Conversion And Management, 142, 523-532. https://doi.org/10.1016/j.enconman.2017.03.051

Marcilla, A., León, M., García, Á., Bañón, E., \& Martínez, P. (2012). Upgrading of Tannery Wastes under Fast and Slow Pyrolysis Conditions. Industrial \& Engineering Chemistry Research, 51(8), 32463255. https://doi.org/10.1021/ie201635w

Meier, D., van de Beld, B., Bridgwater, A., Elliott, D., Oasmaa, A., \& Preto, F. (2013). State-of-the-art of fast pyrolysis in IEA bioenergy member countries. Renewable And Sustainable Energy Reviews, 20 619-641. https://doi.org/10.1016/j.rser.2012.11.061

Mia, A., Murad, W., Ahmad, F., \& Uddin, K. (2017). Waste Management \& Quality Assessment of Footwear Manufacturing Industry in Bangladesh: An Innovative Approach. International Journal Of Engineering Management, 7. Retrieved 11 November 2020, from.

Mkhize, N., Sithole, B., \& Ntunka, M. (2015). Heterogeneous Acid-Catalyzed Biodiesel Production from Crude Tall Oil: A Low-Grade and Less Expensive Feedstock. Journal Of Wood Chemistry And Technology, 35(5), 374-385. https://doi.org/10.1080/02773813.2014.9 84079

Morales, S., Miranda, R., Bustos, D., Cazares, T., \& Tran, H. (2014). Solar biomass pyrolysis for the production of bio-fuels and chemical commodities. Journal Of Analytical And Applied Pyrolysis, 109, 6578. https://doi.org/10.1016/j.jaap.2014.07.012

Murugan, S., Ramaswamy, M., \& Nagarajan, G. (2008). The use of tyre pyrolysis oil in diesel engines. Waste Management, 28(12), 27432749. https://doi.org/10.1016/j.wasman.2008.03.007

National Center for Biotechnology Information. (2020a). PubChem Compound Summary for CID 31292, Octadecanamide. Pubchem. ncbi.nlm.nih.gov. Retrieved 27 September 2020, from https://pubchem.ncbi.nlm.nih.gov/compound/Octadecanamide.

National Center for Biotechnology Information. (2020b). PubChem Compound Summary for CID 8214, 13-Docosenamide, (13Z)-. Pubchem.ncbi.nlm.nih.gov. Retrieved 27 September 2020, from https://pubchem.ncbi.nlm.nih.gov/compound/13-Docosenamide_-_13Z. 
Olazar, M., Lopez, G., Amutio, M., Elordi, G., Aguado, R., \& Bilbao, J. (2009). Influence of FCC catalyst steaming on HDPE pyrolysis product distribution. Journal Of Analytical And Applied Pyrolysis, 85(1-2), 359-365. https://doi.org/10.1016/j.jaap.2008.10.016

Perondi, D., Scopel, B., Collazzo, G., Silva, J., Botomé, M., \& Dettmer A. et al. (2016). Characteristics of Pyrolysis Products from Waste Tyres and Spent Foundry Sand Co-Pyrolysis. Progress In Rubber Plastics And Recycling Technology, 32(4), 213-240. https://doi. org/10.1177/147776061603200403

Pham, X., Piriou, B., Salvador, S., Valette, J., \& Van de Steene, L. (2018). Oxidative pyrolysis of pine wood, wheat straw and miscanthus pellets in a fixed bed. Fuel Processing Technology, 178, 226-235. https://doi.org/10.1016/j.fuproc.2018.05.029

Portuguese Shoes. (2018). World Footwear Yearbook: Intelligence to drive your business. Portuguese Shoes.

Rodrigues, R., Marcilio, N., Trierweiler, J., Godinho, M., \& Pereira, A. (2010). Co-Gasification of Footwear Leather Waste and High Ash Coal: A Thermodynamic Analysis. In The 27th Annual International Pittsburgh coal conference. Istanbul. Retrieved 12 November 2020, from.

Ronsse, F., van Hecke, S., Dickinson, D., \& Prins, W. (2012). Production and characterization of slow pyrolysis biochar: influence of feedstock type and pyrolysis conditions. GCB Bioenergy, 5(2), 104-115. https://doi.org/10.1111/gcbb.12018

Sethuraman, C., Srinivas, K., \& Sekaran, G. (2013). Double Pyrolysis of Chrome Tanned Leather Solid Waste for Safe Disposal and Products Recovery. International Journal Of Engineering Research, 4. Retrieved 11 November 2020, from.

Sethuraman, C., Srinivas, K., \& Sekaran, G. (2014). Pyrolysis coupled pulse oxygen incineration for disposal of hazardous chromium impregnated fine particulate solid waste generated from leather industry. Journal Of Environmental Chemical Engineering, 2(1), 516-524. https://doi.org/10.1016/j.jece.2013.10.006
Sharuddin, S., Abnisa, F., Daud, W., \& Aroua, M. (2016). A review on pyrolysis of plastic wastes. Energy Conversion And Management, 115, 308-326. Retrieved 11 November 2020, from.

Sørum, L., Grønli, M., \& Hustad, J. (2001). Pyrolysis characteristics and kinetics of municipal solid wastes. Fuel, 80(9), 1217-1227. https:// doi.org/10.1016/s0016-2361(00)00218-0

Staikos, T., Rahimifard, S., Heath, R., \& Haworth, B. (2006). End-of-life management of shoes and the role of biodegradable materials. In Proceedings of the 13th CIRP international conference on Life Cycle Engineering (LCE) (pp. 497-502). Bardos; Loughborough: Centre for Sustainable Manufacturing and Recycling Technologies (SMART). Retrieved 12 November 2020, from.

Wei, X., Koo, I., Kim, S., \& Zhang, X. (2014). Compound identification in GC-MS by simultaneously evaluating the mass spectrum and retention index. The Analyst, 139(10), 2507-2514. https://doi. org/10.1039/c3an02171h

Weldekidan, H., Strezov, V., \& Town, G. (2018). Review of solar energy for biofuel extraction. Renewable And Sustainable Energy Reviews, 88, 184-192. https://doi.org/10.1016/j.rser.2018.02.027

Xiao, R., \& Yang, W. (2013). Influence of temperature on organic structure of biomass pyrolysis products. Renewable Energy, 50, 136141. https://doi.org/10.1016/j.renene.2012.06.028

Yılmaz, O., Cem Kantarli, I., Yuksel, M., Saglam, M., \& Yanik, J. (2007) Conversion of leather wastes to useful products. Resources, Conservation And Recycling, 49(4), 436-448. https://doi.org/10.1016/j. resconrec.2006.05.006

Zhang, Q., Chang, J., Wang, T., \& Xu, Y. (2007). Review of biomass pyrolysis oil properties and upgrading research. Energy Conversion And Management, 48(1), 87-92. https://doi.org/10.1016/j.enconman.2006.05.010 